\title{
Meeting of the European Society for Paediatric Research
}

\author{
Brighton, England, June 2'2--26, 1971
}

1. Polygraphic studies (EEG, ECG, motor behavior, and respiration) in hypoglycemic newborns with particular reference 10 seizure activity. C. Motes, F. J. Schelte, and H. LANGENSTRas. six. Uniz. of (xöttingen, Göttingen, Germany.

Elcven newborn infants with blood glucose values below 20 $\mathrm{mg} / 100 \mathrm{ml}$ were studicd by polygraphic recordings lasting 2$6 \mathrm{hr}$. Five infants were born at term and six were preterm. 'Two were infants of toxemic mothers, one was a triplet, and two were small for dates. Four suffered from perinatal brain damage and two had respiratory insufficiency. Hypocalcemia was present in threc infants, hyperbilixubinemia in two infants. Six infants had convulsions, thee were hyperexcitable, and two were hypotonic. Five infants had apnoic spells. All infants had only short periods of well defined slecp states, both active (rapid eye movement (REM) sleep) and quiet (non-REM sleep). Respiration was irregular and rapid. In six infants the EEG showed continuous scizure activity associatcd with convulsions or apnoic spells. In three infants the EEG was inactive either periodically or throughout the entire recording. 'Iwo F.FG's were retarded by 3 weeks. All infants received intravenous glucose cluring the recording, with an elcration of blood glucose above $30 \mathrm{mg} / 100 \mathrm{mI}$. In six infants the clevation of blood glucose did not influence any one of the recorded parameters. Scizure activity as recorded on FEG, convulsions, and apnoic spells increased in three infants while glucose was injected. Only two infants showed prompt improvement of polvgraphic and clinical findings. This effect. howerer, was either of short duration or could not be reproduced during successive periods of hypoglycemia. In conclusion, we think that polygraphic monitoring enables us to differentiate infants with symptomatic hypoglycemia from those with hypoglycemia as a symptom rather than as the caluse of nconatal brain dy'sfunction.

2. Statistical analysis of the clectroencephalographic response to controlled overbreathing in children with epilepsy. D. SCHEFNER and I. Srolzis. Uniu. Children's Hosp., Heidelberg, Germany.

During hyperventilation (HV), thetat and delta waves of three amplitule ranges were summed up for consecutive periods of 30 sec each. pH (PCO.) changes during $\mathrm{HV}$ are directly proportional to the frequency and depth of ventilation, provided that the res. piratory system is intact. Results of correlating quantitative changes of the EEG and acid-base status of 58 children 6-13 years old suffering from generalized or focal epilepsy were compared with the results in 108 healthy children. Whereas in the latter there is an age-dependent increase in amplitude and a decrease in frequency with increased $\mathrm{pH}$ levels, children with epilepsy respond more readily but with less differentiation to HV, their interindividual variability diflering widely. Thus it is not rational to conclude EEG changes from a given pH range. In contrast, a close relationship between EFC $x$ and acid-base status can be found in healthy children. Since our children suffer from epilepsy of early onset, we can only speculate whether lack of differentiated responses in children with epilepsy might be due to loss or immaturity of stabilizing brain function. There is no cvidence so far that children with seizures accuired during school age show the same type of reaction. Therefore we suggest an immature homoiostasis toward HV (alcalosis, hypoxidosis) which is thought to be nonspecific rather than typical for children with epilepsy.

3. The Lennox syndiome: A clinical study of forty children. F. V.ISSEli.A, H. SCHNEIDER, and K. Karibonski. Univ. of Beme, Berne, Su'itzerland.

This type of epilepsy has to be suspected if a combination of various seizures palterns (atonic-akinetic seizures, grand mal, hemiconvulsions) is present in children of 1-6 years of age who are montally retarded. Pcrinatal brain clamage, tuberous sclerosis, intrauterinc cncephalitis due to toxoplasmosis and cytomegalic inclusion disease, and ncurocutaneous melanoblastosis were the etiologic factors discovered in 6 children, the remaining 34 being classilicd as cryptogenic. Age dependency and the different ctiologies lead to the assumption that this type of epilepsy is an unspecific reaction of the brain, during a certain derclopmental stage, to a generally severe clamage.

The typical spike-wave raniant was present at the first EEG examination only in one-fouth of the cases. In half of the patients, the EEG became characteristic only in the course of scveral months or even years. It is therefore postulated that a tentative label of lemox syndrome should be supposed on clinical grounds alone. On the other hand, the diagnosis was suggested on EEC grounds in one-fifth of the patients.

4. Some causal factors in felorile convulsions. S. J. Wathace. and I. I. S. Ingkan. Univ. of Edinburgh and the Roy'al Hosp. for Sick Children, Ldinburgh, Scotland.

Lemox (1960) described felmile convulsions in childhood as "the purest type of epilepsy." This view of febrile convulsions is not shared by many pediatricians who tend to regard febrile convulsions as relatively unimportant. They have, in fact, been compared in significance to rigors occurring with fever in adult patients. Ounsted et al. (1966), on the other hand, have emplasized that febrile convulsions may in themselves be a cause of brain damage, especially in predisposed patients. A serie's of 53 patients between 6 months and 7 years of age who presented in the Royal Hospital for Sick Children, Edinburgh, with convulsions associ- 
ated with fever were studied in detail by Dr. S. J. Wallace. Careful family histories, accounts of the birth (supplemented by hospital notes), and details of the child's development and previous illnesses and the reasons for the admission associated with the convulsion were obtained from the parents. Compared with a control series, a higher proportion of patients suffering from convulsions had a history of being born after abnormalities of pregnancy, labor, and delivery; had a history suggestive of previous neurologic abnormalities; and had a history of virus infections associated with encephalitis (Wallace: 1970, 1971). The fertility of mothers of children suffering from febrile convulsions was studied in the same way as the fertility of mothers of children suffering from diplegic cerchral palsy and (lefts of lip and palate (Drillicn et al.: 1962, 1964; Drillien et al.: 1966). The significance and interclationships of maternal subfertility, abnormalities of sibs, clisorders of pregnancy, labor and delivery resulting in the birth of patients, evidence of precexisting nemrologic abnormalities, and the presence or absence of inclications of encephalitis at the time of the febrile convulsion are considered.

5. Recognition and assessment of the emotional and intellectual consequences of life in an institution. S. Doxiadrs, A. K.IraGir..I, and Y. TrYpHoxopoulou. Bebies Centre Metera, Inst. of Child Hlh, Athens, Greece.

The prevention of retardation or personality distortion, or both, cannot be any longer the only goal of the rearing of infants deprived of normal family life. The other and uppermost goal is the prescriation and cnhancement of the innate individuality of each child. For the cvaluation of this, standard developmental tests are not sufficient. On 30 babies living in the residential nursery bebies Centre Hetera, we used three methods simultaneously for the study of their developenent and behavioral pattern from birth to 20 months: the Bayley tests (new forms), an individuality questionnaire filled out by the mother-substitutes, and interviews between the examiner and the mother substitute. With this approach, we found that initial individual patterns which persisterl in the first 3 months of life showed a tendency for homogenization thereafter, while at the same time the rate of psychomotor development started to slow down in certain fickls. It is only with the usc of such multiple approaches to the assessement of the development of each child that we shall be able to recognize in time all risks ancl to make an early therapentic intervention possible.

6. Immunoglobulin $\Lambda$ and $M$ levels in prematures with an infection of the gastrointestinal tract. C. PApadstos, G.

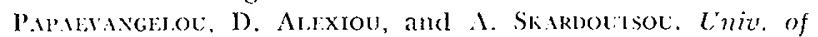
Athens, Alexandra Maternity Hosp., Athens, creece.

The purpose of this study is to present evidence that gastrointestinal (GI) infections of the premature initiate rapid immunoglobulin A synthesis. During an epiclemic of gastroenteritis, it was decided to study all premature newborns with a birthweight of $1000-2000 \mathrm{~g}$. On the basis of clinical and laboratory criclence, 17 of these newborns were considered healthy, while 11 dereloped a bacteriologically confirmed infectious process of the GI tract. There was a spectacular and statistically significant increase of Ig $\mathrm{A}$ in infected versus noninfected prematures. These results support the concept of local antibody synthesis and suggest that the intestinal antibody system responds rapidly to local antibody stimulation resulting from the aquisition of a pathologic intestinal microbial flora. It is suggested that microorganisms causing localized infections of the GI tract stimulate immunoglobulin-producing sites of the intestinal wall. This results in rapid production of sccretory antibody. In the course of this localized infection, replication of bacteria in the lymphoid tissue of the intestinal wall stimulates immunologically competent cells in direct proximity to the alimentary tract, causing increased scrum Igil levels.

7. The immunoglobulins and coproantibody formation in infants aftcr artificial colonization of the intestinc with Escherichia coli OS3 and lyzozyme administration. R. Lodrovi V. WAGNir, and V'. Jouja. Inst. of Care for Mother and Child, Prague-Podoli, Ciechosloz'akia.

The development of immunoglobulins in stool filtrates and scrat was followed in bottle-fed infants artificially colonized with a nonpathogenic lischerichia coli strain, infants treated with lyzozyme, and breast-fed infants.

Immuoglobulins were determined by radial immunodiffusion, antibodies against $E$. coli 083 by hemagglutination technique. In colonized infants, xather than in controls, an carlier occurence of $\operatorname{IgA}$ and $\operatorname{Ig} \mathrm{Ml}$ and higher titers of antibody in stool filtrates and sera were found. The secretion of $\operatorname{Ig} A$ in the intestine of lyzorymetreated infants was elecreased. The breast-fed infants showed high levels of $\operatorname{Ig}_{i} \mathrm{i}$ in stool tiltrates, passively transferred from maternal milk. The anificial colonization represents a strong antigenic stimulus which caused a high and early antibody response in serum and intestinal mucosi. This accelerated immunologic reactivity might be the basis of a defense mechanism in infants who are not protected by passively transferred antibodics against enteral infections. Lyozyme might influence the intestinal flora and decrease the production of secretory Ig: 1 in the intestine.

8. Elimination fiom plasma of gamma globulin fragments following substitution in immunologic deficiency. F. W. BL.ikt:R and K. Mar. Lniv. Kinderklinik and Inst. for Mikrobiol. and Im. munol., Lniv. of Hamburg, Hamburg, Germany.

Investigations were performed to determine the duration of passive immunity needed to prevent infection in immunologically deficient children.

Pepsin-digested human gamma globulin was administered to paticuts with and without agammaglobulinemia. The elimination of the gamma globulin fragments and their antibody functions from the plasma were measured by means of singte radial immunodiflusion lests and by tetanus antiboly titration (passive hemagglutination). 'Iwo fractions could be identificd, both containing antibody activity. Onc of them, obviously the main fraction, has a sedimentation constant of $5,3 \mathrm{~S}$ and a half time of disappearance of $12 \mathrm{hr}$. The second, a minor fraction with a seclimentation constant of $3,5 \mathrm{~S}$, is eliminated from the plasma with a half-time of $35 \mathrm{hr}$. Less than $5 \%$ of the administered amount was recovered in active form in the urine.

9. Inborn defect of immunological function: Absent antibody' formation without decreased concentrations of serum immunoglobulins or of peripheral lymaphocytes. A. Russfit. G.

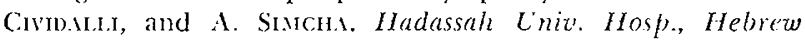
Eniv. of Jerusulem, Jerusalem, Israel.

presentation was of a boy of 10 years with profound systemic 
Salmoncilosis but without scrologic response. An unclexlying pattern of episodic if not chronic salmonellosis since 18 months emerged, accompanied by recurent pneumonia and abscesses, 10 gether with chronic moniliasis and gross growth failuce. He had delayed healing after chickenpox and vaccinia immunization. $A$ sister and brother succumbed suddenly at 2 years and 5 months, respectively. While levels of three major immunoglobulins were normal, even increased, there was complete absence of circulating antibodies. greatly depressed delayed type skin hypersensitivity. and prolonged skin homograft rejection. I ymphocytes and plasma cells appeared normal morphologically and numerically, although in ritro lymphocyte transformation with phytohemagglutinin was markedly reduced. Neutrophils were normal in number and function. Fvidence for a new partial immunologic deficiency syndrome compared with kindred states is apparent.

10. Mctabolic and morphologic studies of blood lymphocytes in the neonatal period. V. ANDERsen, E. ANDERSEN, and 13. IFIIS-HANSEN. Rigshospitalet, University' Hosp., Copenhagen, Denmark.

The development of lymphatic tissue in the neonatal period as a consequence of antigenic stimulation has been studied in animal experiments. In lymphocytes, increased synthesis of RNA and protein and increased mitotic aclivity is found. In this study, blool lymphocytes of infants were examined at birth and at daily intervals thereafter. Their number and morphology were assessed, and the changes in RNA and DNA metabolism were studied through their in zitro incorporation of tritiated cyticline and tritiated thymidine, followed by autoradiography. The findings in normal infants were compared with the results obtained in newborns with infections.

11. Enzymatic studies on phytohemagglutinin-stimulated lymphocytes. S. Nordo, A. Marchi, and M. A. Marchi. Unio. of Trieste, Trieste, and Univ. of Genon, Genoa, Italy.

In a previous paper, the American Association presented first results of an investigation on the lysosomal enzyme activities of the phytohemagglutinin-stimulated lymphocytes of patients with celiac discase and a few other pathologic conditions with immumologic defects.

They continued these investigations by studying: (I) lysosomal cnzymes (before and after treatment of the culturel lymplocytes with Triton) in relation to immunologic problems; (2) lysosomal and other enzrme activities in relation to cystic fibrosis of the pancreas and a few other inborn crrors of metabolism (galactosemia, sulfaticlosis, PKL). The sensitivity of the test of phytohemagglutinin-stimulated lymphocytes is increased by the enzymatic deteminations. The interest of this new approach to immunologic and metabolic problems is emphasized.

12. Subacute sclerosing panencephalitis (SSPE): Differences between moasles virus and viruses isolated from SSPE brain cells in culture. V. Ter Mrclen, M. Katt, M. Y. Käckel., G. Barbanti-Brodano, and H. Korrowskr. Univ. of Götlingen, Göttingen, Germany, and the Wistar Inst., Philadelphia, Pennsyltania, USA.

Differences between measIes virus and isolated SSPE viruses have been demonstrated previously in their infectivity for ferrets and hamsters. To compare some properties of these viruses in vitro, tissue cultures were infected with a wild strain of measles virus, the attenuated Edmonston strain, and two SSPE viruses.
African green monkey kidney (AGMK) and human embryonic kidncy cell cultures were found to be susceptible to the four viruses. When, however, human brain cell cultures, derived from patients with CNS diseases other than SSPE and from normal human embryos, were exposed to these viruses, they became infected only with the two types of measles virus and not with SSPE viruscs. Kinctic experiments of SSPF viruses of different passage levels suggest that a large proportion of incomplete virus particles inhibiting infection accounts for the resistance of the brain cells. AGilk cells infected with the four viruses showed positive cytoplasmic staining by fluorescence microscopy in the presence of SSPE sera and carly and late neasles convalescent sera. When SSPE sera and carly convalescent measles sera were used, immunofluorescence was also observed in the nuclei of the infected cells, except in those cells infected with the Edmonston strain of measles virus. Cells infected with SSPE. viruses exhibited only two types of intranuclear fluorescence: speckled and inclusion type. These data suggest that the SSPE viruses are not identical with measles virus, and that host response to them differs.

13. Gestational and growth characteristics of a neonatal popu-

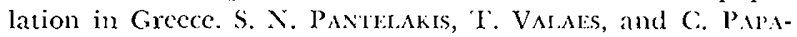
Datos. Inst. of Child Hllh, and Univ. Matermily Hosp. "Alexandra," Athens, Greece.

Thirteen thousand nine hundred twenty-six consecutive births during a 2-year period (1960-1968) in "Alexandra" Maternity Hospital, Athens, were studied in terms of the reproductive and sociocconomic characteristics of the mothers and the intraturerine growth of their newbons. Eighty-four per cent of the mothers belonged to the lower socioecononic group and $18 \%$ were primiparac; $10.5 \%$ of the newborns were preterm and $6.5 \%$ postterm, and the gestational age distribution curve was clisplaced toward shorter gestation by $3-4$ days in comparison with the distribution in the British Perinatal Mortality Survey. A definite slowing of growth rate was evidcut after the 37 th weck of gestation. This slowing of growth during the last 3 weeks of pregnancy, and the tendency toward shortcr gestation might be an indication of limited capacity of the maternal environment to support fetal growth in this population.

14. Amniotic fluid total hydroxyproline and intraterine growth. 13. A. Whatton, J. W. Folids, I. D. Frasfr, and C. A. PeNrock. Inst. of Child Mlth., London, England.

In normal pregnancy, amniotic fluid total hydroxyproline concentration rose to a peak around the 28 th week before falling steadily to term, while a creatinine concentration was at first constant and then rose rapidly to maximum values at term. The total hyproxyproline/creatinine ratio reached a zenith around 17 wecks and then fell rapidly. Total hydroxyproline concentrations tended to be Iower in those pregnancies producing small for dates babies and those at particular risk of intrauterine growth retardation. The total hydroxyproline/creatinine ratio in the first urine passed by babies was a little higher than the amniotic fluid from the pregnancy concerned. After birth, the urinary ratio rose rapidly. There is some cvidence that changes in ammiotic fluid total hydroxyproline and total hydroxyproline/ creatinine ratio are related to intrauterine growth. Further information, particularly from other animals, is required. A determination of amniotic fluid-total hydroxyproline may crentually prove to be clinically useful when romsidering in- 
duction of labor for preclampsia, or maternal loss of weight towarl term, but a more intensive study during this period of pregnancy will be neccsary before firm, clinically useful conclusions can be made.

15. Late effect of carly malnutrition on physical and mental development: Follow-up after 22)-12 years. (. Br:ReLcivo and F. R:130. Univ. of Golhenlurg, Göteborg, Sweden.

The romaining 180 of the 203 patients treated for hypertrophic pyloric stcnosis during the years 1922-19.12 at Children's Hospital, Göteborg, were interviewed and their height and intelligence test results at the time of registration for military service have becn inrestigated.

Comparison of their heights with the mean height of the male population showed slight differences. Comparisons with the heights of their brothers showed that the patients were shorter than the brothers. The difference was more pronouncel when the patients had suffered a more severe mahurition. At the intelligence lest, only those who had suffered the most severe malnutrition demonstrated slightly lower values. The adlaptability test demonstrated that the greater the malnutrition, the lower the score.

16. Reduced nicotinamicle adenine dinucleotide (NADH)-dependent diaphorase isocnzymes in the newborn. G. Werprex, M. Panturschko, and W. Kossis. Univ. of Vienna, Viemna, Austria.

There are two isoenzymes of the NADHI-dependent diaphorase (methemoglobin reductase) in the adult, with an activity of $30 \%(A)$ and $70 \%(B)$. In the newborn we lind the same two isocnzymes with another relative activity. In consideration of the lowered activity of the whole enzyme in the newborn $(70 \%$ of the adult) the activity of the fraction $A$ is the same as in adults, $30 \%$, and fraction $B$ has only $40 \%$, contrary to $70 \%$ in adults. Therelore. the cause of the diminished activity in the whole cmatre is only the lowered activity of the isoenzyme B. Methot: cellulose acelate clectrophoresis. The enzyme with NADH reduces dichlorphenol-indophenol (DCIP) and DCIP reduces dimethylthiawlyl-tetrazoliumbromide under the action of phenarin-metasulfate as $\mathrm{H}^{+}$transfer substance to formakan. Formazan was measured spectroscopically.

17. Diazepan metabolism in premalure infants. P. I.. Moksfatr.i,

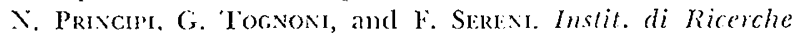
Farmacologiche M. Negri and Lnin. of Milan, Milan, Italy.

While it is well known that in newbom animals the activity of liver dhug metabolizing enzymes is defective and the rate of metabolism of foreign compounds greatly impaired, very few data are available for newborn infants. Investigations werc performed in orelex to evaluate in newborn and premature infants the rate of metabolism of diazcpam (1)\%), which in mature subjects undergoes demethylation, hydrox yation, and conjugation. Plasma and urinary levels of $\mathrm{D} \%$ and its molabolites were measured by gas chromatography. $0.3 \mathrm{mg} / \mathrm{kg}$ DZ (intramuscularly, single dose) led to higher plasma clarance, in comparison with values obtaincd in children. No significant differences in plasma levels of $x^{-}$-demethyl-diatepam were observed. While in children significant amounts of hychoxylated and conjugated metabolites ( $N$-methyl-oxazepam and oxazepam) were present, not even traces of such compoumls were detected in urine of premature infants. Biochemical and clinical implications in terms of devclopmental pharmacology are considered.

18. Interaction betwecn human placental alkaline phosphatase and ABO system polymorphisms. E. BOTTNI, P. LUCARELLI, P. Pigran, R. Palmarino, G. F. Spennati, and M. Orzaniest. Vatl. Res. Council, Cintr. of livolutionary Genetics, Rome, Italy, and Yale Univ., Neru Haven, Conn., USA.

placental alkaline phosphatase (Pl) shows an clectrophoretic polymorphism determined by three common alleles, as well as by other rarer ones at an autosomal locus. The gene is normally active cluring intrauterine life only, and the enzyme, produced by the fetal part of placenta, is present at an carly stage of pregnancy in the maternal blood stream. Considering that an association with the ABO system has alrearly been described for another alkaline phosphatase, namely the intestinal onc, our present investigation was undertaken with the purpose of finding out a possible interaction between the Pl polymorphism and the $A B()$ one during intraucrine life. Recently, Bechman reported that the six common phenotypes of placental alkaline phosphatase show different cncymatic activities both in pregnancy serums and in placental cxtracts. Ninc hundred thrce placentas, collected during the period from September 1968 to September 1970 at the Yale- $Y$ cw Haven Hospital and belonging to at white population of European origin, were examined. The results have shown that, in the newborn babies incompatible with the mother in the ABO system, the incidence of Coombs' test positivity or jaundice (as referred to the single common Pl phenotypes), or both, ate correlated in a linear fashion with the encyme activity associated to the various PI phenotypes in the scuse that the lower the enzyme activity, the higher is the incilence of these signs. Several other lincs of evidence found in the course of our investigation faror the hypothesis of a complex interiction involving $\mathrm{ABO}$ and $\mathrm{Pl}$ polymorphisms at various stages of intrauterine life. Because the intensity of action, at the level presently considered, appears in a fairly crident relation with the enzyme actirity associated to the alleles of one of the interacting systems, a quite reasonalsle basis does exist for further investigation of the interaction mechanism.

19. The infuence of glucagon and phenobarbital on enzymes of carbohydrate metabolism in the developing rat liser. J. Scrtal's and $\mathrm{F}$. IREShA. Children's tlosp. of the Unit. of Munich, Munich, Germany.

In rat liver the following enymes are measured from the 1 , th fetal to the 20th neonatal day: G6PDH, 6PGDH, PGAr, PGI, FDPase, phosphorylase, FoPK, HK, $\alpha$-glucosidasc, G6Pase, glycogensynthetase $a$ and $b$. Gilucagon was injected cither into the abdomen of each fetus after opening the abdeminal wall of the mother or intraperitoncally to each newbom rat. Phemobarbital was injected three times in an interval of $24 \mathrm{hr}$ either to the littermates or to the newborn intraperitoneally.

A striking effect of glucagon is seen on the two foums of glycogensmethetase. l)uring fetal and neonatal life, the enzyme is significantly inhibited by the hormone. A small effect is scen on PG.Y: this enzyme is activated during development. The effect of glucagon on the other enzymes measured is not significant. The most striking effect of phenobarbital is seen on phosphorylase. The activity, either measured with the optical test or with phosphorus release is decreased 1.5 -fold during the neonatal period. The independent form of glycogensynthetase is dc- 
creased 1.5-fold during the 5th and 20th neonatal day. The lysosomal $\alpha$-glucosidase is activated 1.5 -fold by phenobarbital before and after birth.

20. Ontogeny of iminoglycine transport in the kidncy. K. BAfRLOCHER, C. R. SCRIVER, and F. Moh'uddin. Uniu. Children's Hosp., Zurich, Switzerland, and Mccill Lniv, Montreal Children's Hosp. Res. Inst., Montreal, Quebec, Canada.

In human and rat kidncy glycine, r-proline and $\mathbf{l}$-hydroxyproline are transported by three different systems: a common system with high capacity and low affinity which is shared by all three amino acids and two specific systems, one for proline and one for glycine, both with high affinity and low capacity. Since human and rat ncwborns show a transient hyperexcretion of these amino acids in urine, one may ask whether it is a decrease in the activity of all systems or rather a transient deficiency in one of the systems which accomts for the "immaturity." Therefore, we investigated developmental aspects of the iminoglycine transport in vitro by means of kidney cortcx slices in 1-, 2-, and 3-week-old rats. Initial rates of uptake are reduced in the newborn kidney at low substrate concentration when compared with the adult kidney; during longer incubation newborn kidner slices accumulate more substrate reflecting reduced rate of eflux. Kinctic analyses reveal the absence of the low $K_{m}$ systems for proline and glycine in the l-week-old rat. $\mathrm{At}$ 2 wecks, the low $K_{m}$-proline system appears, and at 3 weeks the low $K_{m}$-glycine system. Cyanide and anoxia inhibit the available high $K_{m}$ transport. The deficiency of transport is therefore due to a lack of carrier and not of the coupling of the carrier to energy. $r_{\text {mux }}$ 's for proline and glycine uptake on the present high $K_{m}$ carriers increase equivalently with age. Thus, changes in specific activity of membrane sites and in total membrane activity characterize transport ontogeny in kidney.

21. Fructose in the dict of diabetic children. It. K. Áreribom,

I. Sir.tax.x, and A.-K. Kar.t.o. Children's Hosp., Univ. of Helsinki, Helsinki, Finland.

The object of the study was to evaluate whether fructose can safely be used as a sweetening agent in the dict of diabetic childien. At first, short term effects of fructose were stuclied in 26 hospitalized cliabetics by administering fructose $1 \mathrm{~g} / \mathrm{kg}$ body wcight at breakfast and comparing for $3 \mathrm{hr}$ postcibal levels of blood glucose to those of control days, when a corresponding amount of calories was given at breakfast in a regular diet for diabetics. The postcibal hyperglycemia was significantly smaller on "fructose" days as compared with control days at 30, 60, 90, and 120 min. For the time being, we are studying whether a longer lasting use of fructose has any effect on the control of childhood diabete's. Ten subjects took at home every 2 nd weck a diet containing $1.5 \mathrm{~g}$ fructose, $\mathrm{kg} / 2 \mathrm{th}$, alternating for $\mathrm{I}$ weck with a regular diet for diabetics with the same amount of calories. The children were studied for 4 weeks, and the dose of insulin remained constant. Glucosuria was recored twice daily by "Clinitest" and ketonuria by "Kctostix," and at the end of cach week 24-hr glucosuria was measured. No significant differences were found in glucosuria and ketonuria between control and "fructose" weeks, suggesting that fructose could be used as an alternative for swectening of food for diabetic children. If fructose is used, a corresponding amount of other carbohydrates should be deducted from the diet.
22. Therapeutic ketolysis in ketoacidosis without use of insulin. J. R. Bhericil, K. RAGer, and G. BrügaAan. Univ. Kinderklinik, Tübingen, Germany.

It is our future object to remove the ketone bodies in ketoacidotic patients by means of substances which stimulate the TCA cycle. Here oux aninal experiments are reported. Groups of 10 rabbits each (5, $48 \mathrm{hr}$ fasted; 5, alloxan diabetic) were infused with (I) lactate, (2) pyruvate, (3) malate, (4) alanine, and (5) asparagine; 0,30 , and $300 \mathrm{~min}$ postinfusion, scrum was examined for: glucose, F FA (according to Duncombe), acctoacetate $(\Lambda \Lambda)$, $\beta$-hydroxybutyrate (OH-but), and pyruvate, using the enzymatic method according to Bergmeyer and Bernd. Results of fasted animals which showed no severe ketosis are not reported here. AA and OH-but were cnhanced 30 times in nontreated diabetic rabbits and decreased after infusion of each substance used. Decrease was maximal after lactate (to 30 and $35 \%$, respectively, of the starting values of $A A$ and OH-but) and pyruvate (to $35 \%)$. ketoly'sis was alway's connected with hyperpyruratemia.

23. Secretin induces renal bicarbonate loss in man. O. OrTlıkr:R, H. B. HAdorn, and A. Cintris. Univ. of Berne, Berne, Süitzerland.

The gastrointestinal hormone secretin stimulates bicarlonatc excretion in the pancreas and the liver. A number of hypotheses have been pul forward to explain the mechanism of action of this hormone [1]. In a search for targets of secretin, we tested its influence on bicaloonate realssorption in the kidney: in three patients who underwent "renal bicarbonate titration studies" [ㅇ], the handling of bicarbonate, sodium, titratable acid, and ammonia by the kiclncy was tested before and after adding secretin to an infusion of sodium bicarbonatc. Cuder the influence of secretin $(80 \mathrm{~L} / \mathrm{hr} / \mathrm{ml})$ more bicarbonate was excreted and the excreted fraction of filtered sodium was significantly higher than in the control period. By contrast, less titratable acid and ammonia were excreted in the prescnce of secretin.

The data are interpreted to indicate that secretin inhibits sodium reabsorption and hydrogen ion excretion, and thereby increases bicarbonate loss in the human kidney.

I. Grossman, M. I.: Lancet, $i$ : 1088 (1970).

2. Oetliker, O., and Rossi, E.: Pediat. Res., 3: 140 (1969).

24. A compensated hemolytic process in rats due to a decreased lipid exchange between plasma and crythrocyte membranes. l'. HǘTrk. Univ. of Hamburg, Hamburg, Germany.

Hypolipemia (decreased plasma cholesterol, phospholipids, and FFA, and altered patterns of FFA and fatty acids esterified with phospholipids) in rats was induced by applications of CPIB (ethyl-p-chlorphenoxyisobutyrate) (200 $\mathrm{mg} / \mathrm{kg}$ body weight, 24 hr). Due to decreased lipid content of plasma, the active and passive incorporation of cholesterol and phospholipids into the erythrocyte membrane were reduced. The continuous lipid loss of the membrane could not be compensated for. An increased hemolytic process and a compensatory increased erythropoiesis could be demonstrated: crythrocyte count decreased by $10 \%$ and ${ }^{51} \mathrm{Cr}$ life span decreased by $50 \%$; there was an increase of MCV, MCD, MCSA, and MCH, and a decrease of MCHC. The membranes of young crythrocytes contained significantly more phospholipids and cholesterol. The patterns of the fatty acids esterified with the phospholipids were altered according to those it the plasina. 
25. (ilvcogenosis type I: A membrane discase: R. Grizfram and M. A. Sricher. Univ. of Zïrich, Zürich, Switzerland.

An ultrastructure study of parenchymal cells obtained from the liver and from a stemmed liver tumor of a patient suffering from glycogenosis type I revealed gross abnormalities of the endoplasmic reticulum, i.e., of the cellular organelle with which the enzyme glucose 6-phosphatase is normally associated. An uncommon type of "resiculation" of the rough ER was found [1]. The structural lesions may be causally related to a primary effect of the mutation on some membranes as was recently postulated for radiation-induced glucose 6-phosphatase deficiency in albino mice. If this were indecd the case, glycogenosis type I would seem to fit into the concept of "enzyme integration mutants" [?].

1. Spycher, M. A. and Gitzelmann, R: Glycogenesis type I (glucose 6-phosphatase deficiency): ultatstructural alterations of hepatocytes in a tumor-bearing liver. Virch. Arch. A. B. Zellpathol. (in press).

2. Paigen, K.: The genetics of enzyme realization. In: M. Rechcigl: Enzyme Synthesis and Degradation in Mammalian Systems. (Karger, Basc'l, 1971).

26. Glycogen metabolism in normal and glycogen-rich red blood cells. S. II. Mosfs and X. Bashax. Central Neger Hosp. and Negey Unia', Beer-Sher'a, Israel.

Evidence for active glycogen metabolism involving synthesis and breakdown, present in both normal and glycogen-rich exythrocytes, obtained from patients with glycogen storage disease type $I I I$, was provided by incorporation studies of glucose- $\mathrm{C}-{ }^{14} \mathrm{C}$ into erythrocyte glycogen. The kinetics of glvcogen synthesis and breakdown was studied by varying incubation conditions. Incorporation rates showed a ph maximum at 7.6 . Sodium was found to stimulate incorporation rates more than potassium. Phosphate requirement was cstablished and sodium fluoride has an inhibitory effect on this reaction. Stuclies cmploying $\beta$-amylolysis showed that the main metabolic activity of erythrocyte glycogen affects its outer tiers. both in normal and glycogen-rich erythrocytes. The characteristics of exythrocyte glycogen synthetase were studied and arc considered.

27. Clinical, biochemical and histologic observations in a case of so-called "I-cell discase." W. Nützrnadel, K. H. Lichtr, K. SCHÄkLR, and A. K. Rossirr. Children's Hosp. of Lniv. of Iteidelberg, Heidelberg, Germany.

In 1968 leroy and De Mars described two children with numerous cytoplasmic inclusions in cultured fibroblasts, mental retardation, and Hurler-like clinical features. Spranger and Wiedcmann reported in 1970 six additional cases. We observed a child with identical changes of the cultured fibroblasts and a similar clinical course. At the age of 2 months the legs were swollen and $x$-ray examination revealed periostal new bone formation and signs of atypical rickets at the end of lower metaphyses of the femur. Later, the skeletal disturbance became more severe, with generalized decalcification and deformitics of many bones. The child suffers from severe mental retardation, myoclonic seizures, and a progressive limitation of joint mobility. Other striking clinical lindings are a peculiar face, an extremely hypertrophic gingiva, a hoarse voice, and a pale, tight and firm skin. Laboratory data are normal excent for the increase in excretion of phosphate in urine and alkaline phosphatase in the serum. In liver tissue, some lyosomal hydrolases are high and the content of mucopolysaccharides seems increased. The histologic studies of liver, kidney, and bone manow show only slight alteration in the sense of a storage disease. The investigation of brain tisste by light and electron microscopy gives a picture similar to that of orthochromatic Ieukodystrophy. Biochemically, the content of Iipids in the white matter and that of the glucolipids in the gray matter of the brain are somewhat low. Our studies conceming the estimation of enzymes and the chemical nature of the stored material in the fibroblasts axe in progress.

28. The skeletal abnormalities in patients with homocystinuria duc to cystathionine sunthase deficiency. D. P. Brfonos. Lniv. Coll. Hosp. Med. Sch. and Galton Labs., Univ. Coll., London, England.

The purpose of this communication is to describe the skeletal abnormalitics of 22 patients and to correlate them with other clinical and biochemical features. Skeletal abnormalities were mild in 10 , moderate in 5 , and severe in 7 . The long bone metaphyses and the vertebrae have a characteristic appearance in severe homocystinuria. These appearances are illustrated together with details of percentile heights and body proportions. and so forth. Mental retardation secms to be more common in patients with severe skclctal abnormalities. Two patients without lens dislocation and three with dislocations occurring after the age of 10 years had mild skeletal featurcs. Patients with mild skeletal and other clinical features nearly always show a good biochemical response to pyridoxine, but the response of sererely affecterl patients is less predictable.

29. Renal functions in hypophosphatasia. K. Mínes and I.. Ki.cjвеR. Univ. Med. Sch., Pécs, Hungary:

In a previous study of hypophosphatasia, we reported impaired tubular reabsorption of phosphates in two homozygous patients (ESPR Mecting, Stockholm, 1970).

Since then, altogether 5 homozygotes and 16 lietcrozygotes have been observed, partly as a result of a screening progran, in our clinical material. The diagnosis of the juvenile type of hypophosphatasia was confirmed by decreased alkaline phosphatase activity in the blood and urine, and by the cxcretion of phosphocthanolamine. In all these paticnts, renal functions proved to be normal, but the tubular reabsorption of phosphates was significantly impaired in the homozygotes, and slightly, but consistently, reduced in the heterozygotes. This feature was found to be unchanged under a variety of conditions including phosphorus loading and phosphorus-free diet. Calcium loading tests of two homozygotes showed nomal response of the parathyroid gland. Examinations of amino acid and glycosaminoglycan cxcretion revealed normal patterns.

Although the exact pathomechanism is still unknown, the impaired tubular realssorption of phosphates seems to be a characteristic feature of the discase, and might be useful cren in the detection of heterozygotes.

30. Protein synthesis in human leukocytes. Dependency of aminoacid incorporation on intra- and extracellular concentrations of amino acids in cell suspensions and cell-frec systems. $K$. WINKLER, G. HeI.LER-SCHöCH, and R. NETH. Universitätskinderklinik Hamburg Eppendorf, Germany.

The incorporation rate of labeled amino acids into protein of human leukocytes is inhibited in vitro by the presence of other 
amino acids in the culture medium. It is shown that this inhibition is not caused by reduced protein synthesis, but is the consequence of the known competitive inhibition of amino acid uptake by intact cells. In the presence of high concentrations of phenylalanine, no inhibition was clemonstrable in cell-free systems of human tonsils, neither in aminoacyl-tRA synthesis, nor in mRNA.dependant binding of aminoacyl-tRNA to ribosomes, nor in the peptidlyl-transfer reaction. Correspondingly, the incorporation ratc in the $30,000 \times g$ supematant of homogenate of human tonsils was unchanged by high concentrations of phenylalanine. In conclusion, it is assumed that clirect inhibition of translational processes of protein synthesis does not play an essential role in the pathogenesis of phenylketonuria. However, a reduction of protein synthesis by other mechanisms, e.g., substrate deficiency or reduced RNA synthesis, is not excluded and mav take part in the pathogenesis of phenylketonuria as is suggested by the results of other authors.

31. The statistical distribution of amino acicl concentrations in plasma. H. WICK, T. BrFChï̈HIFR, C. BACHMANN, and R. Baumgartier. Lniv. Children's Hosp., Basel, Switzerland.

The Caussian distribution of normal values of amino acids is usually taken for granted. A large sample $(n>50)$ for phenylalanine and tyrosine was collected. These amino acids follow a lognomal distribution more closely than a lin-normal distribution. Preliminary results with other amino acids showed that some may be symmetrically distributed while others are not. It would be of great practical importance if one could ascertain an asymmetric beharior, as it would prevent unnecessary and disturbing examinations in many normal children.

32. Importance of physical forces and the control of tubular sodium reabsorption. A. Aprris, O. Broberger, and $S$. Söblekicixd. Karolinska Inst. and s:t Göran's Childien's IIosp., Stockholm, Sweden.

The purpose of the present study was to establish the importance of physical forces: i.e., peritubular, hydrostatic, and oncotic pressure for the control of tubular sodium reabsorption in experimental animals and in man. (I) The effect of variations in renal artery perfusion pressure on the tubular sodium reabsorption has been examined in the in situ-perfused dog kidney. Renal artery perfusion pressure increases suppressed tubular sodium reabsorption in the entire nephron but predominantly in the proximal tubule. This effect was, however, abolished by increases in peritubular capillary oncotic pressure which was accomplished by renal artery albumin infusion. The results clearly demonstrate the importance of physical forces in the control of tubular sodium reabsorption. (2) Deviations from normal conditions in peritubular phrsical forces is to be cxpected in paticnts with abnormal renal artery perfusion pressure and in patients with high hematocrits, since high hematocrits will increase the filtration fraction and thereby the peritubular capillary oncotic pressure. For this purpose, the control of sodium reabsorption was studied by determining the elimination of an acute sodium load in patients with $(A)$ various levels of renal antery perfusion pressure, i.e., before and after opcration of coarctatio aorta, ancl (B) children with high hematocrits: infants and children with cyanotic heart diseases. Glomerular filtration rate, PAH clearance, and sodium reabsorption were determined in each study. A significant correlation could be found both between renal artery perfusion pressure, filtration fraction (changed as a function of hematocrit), and tubular sodium reabsorption. Cilinical importance of physical forces for the control of soclium reabsorption is thereby cstablished.

33. Control of sodium homeostasis in children with recurrent urinary tract infections and reduced glomerular filtration xates. A. AreriA, $\boldsymbol{C}$. Berg, and O. Broberger. Karolinsha Inst. and sit Göran's Children's Hosp., Slockholm, Sueden.

Basal sorlium excretion and rapid response to oral and intravenous sodium loads have been studied in children with recurrent urinary tract infections and a wide range of glomerular filtration rate. Basal sodium excretion related to body surface was remarkably stable in all children studied and was thus independent of glomerular filtration rate. The rapid response to an oral or an intravenous sodium load was reduced in patients with low filtration rates. The urinary sodium excretion rate following oral sodium load was correlated to the glomerular filtration rate with high statistical significance. In patients with high filtration rates, saline infusion resulted in a rather prompt inhibition of tubular sodium reabsorption with consequent increase in urinary solium excretion. In patients with low filtration rates, inhibition of tubular sodium reabsorption following intravenous saline load was much less pronounced. During the transition from hydropenia to water diuresis without extra sodium supply, both the patients with low and with high filtration rates increased the absolute as well as the fractional sodium excretion concomitantly with an increase in the filtered load of sodium. The results are compatible with. but do not prove the existence of, an aclditional natriuretic factor that keeps the basal solium excretion constant in the diseased kidncr.

34. Sandhoff's discase: Total deficiency of hexosaminidase (A and B) as cause for accumulation of globoside $G_{X 2}$ and asialo $G_{M 2}$. W. KRIVIT. II. Sharp, P. SNYDFr, and R. DFsivick. L'nit. of Minnesota, Minneapolis, Minnesola, USA.

Sandhoff in 1968 noted hexosaminiclasc activity to be totally deficient in a paticnt with clinical symptomatology of Tay. Sachs discase. The differences between these discase's is apparent from the following:

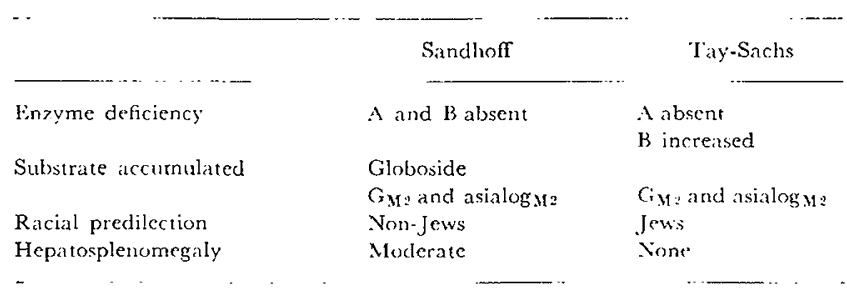

Inclividual case reports from several centers indicate that frequency of Sandhoff disease is much greater than had been considered. We have established the above enzyme deficiency and substrate accumulation in two siblings in a family of nomJewish ancestry. Since the enzyme is present in normal plasma, an atcmpt at enzyme replacement by plasma infusion was made. The level of enzyme rose in proportion to amount infused. Hepatic tissuc obtained by percutaneous biopst was assayed for enzymatic activity before and after plasma infusion. The conclusions from these studies are that the new diagnostic techniques and therapeutic ventures have increased importance 
in correctly diagnosing the underlying defect of degenerative central nervous sistem disorders.

35. Recherclie d'une consommation intra-vasculaire par une étude in rizo de la cinćtique du fibrinogène plaquetes $" \mathrm{Cr}$. M. Drechavanive, $F$. Bertholx, J. P. 'Imolverez, J. J. Viala, and D. Grimian. Labor. Ctr, Hematol. Hoptal L. Herriot, I.yon, France.

le but de ce travail est de mettre en éridence une consommation intra-vasculaire subaigüe ou chronique, en étudiant simultanćment la cinétique des plaquettes du malade, marquées au ${ }^{\text {sC }} \mathrm{Cr}$ selon la technique d'Aster et Jandl, et celle d'un fibrinogine lyophilisé marqué auparavant au ${ }^{195}$ sclon la technique de MacFarlane. Dans huit cirhoses avec splénomégalic et thrombopćnic, le taux quotidien du fibrinogienc dégradé est normal, le pourcentage maximum de plaquettes circulantes trésabaissć, et le $T_{1 / 2}$ plaquettaire modérément diminué. Ainsi la thrombopénic n'est pas la conséquence dlune consommation intra-splénique, mais elle tlatuit l'augmentation du pool plaquetaire splénique. Par contre, dauns deux hépatites virales aiguës, le taux quoticlien de dégradation du fibrinogène est très augmenté et le $\mathrm{I}_{1 / 2}$ plaquettaire tries climinué. Ces arguments plaident en farcur d'une consommation intra-vasculaire dans les hépatites.

36. Fibrin degradation products in the urine of children with renal discase. $X$. M. BarratT, C. Chantrer, and H. EkERt. Inst. of Child Hllh., London, England.

fibrin degradation products (FDP) were assayed by the tanned red cell hemagglutination inhibition technique in the sera and urine of children with renal disease, and were related to other parameters of proteinuria. Lrinary FDP cxcretion was greater in inclivicluals with poorly selective proteinuria; within the poorly selective group there was also a significant correlation between FDP excretion and albumin excretion. No correlations were observed with (ub)uar protcinuria, hematuria, or serum liDP levels. Lxinar IDP may axise from intravascular coagulation confined to the kidney or from fibrinogen filtration and fibrinolysis in the urimary tract; the data presented are compatible with either hypothesis.

37. Coagulation abnormalitics in acute meningococcemia: Results of early heparinotherapy. J. Dibors, P. Fondu, and D. BL.u.r. Univ. I.ibre of Bruxelles, Brussels, Belgium.

Coagulation abnormalities were related to the clinical state of 48 patients with meningococcemia (shock, preshock, or absence of any cardiocirculatory abnormalities).

Characteristic coagulation abnormalities, i.e., prolongation of prothrombin time secondary to depression of factors VII and $\mathrm{X}$, prolongation of partial thromboplastin time, and diminution of platelet count were already observed in most cases of preshock, but in a few cases were already present before any symptom of circulatory abnormalities. Severely decreased fibrinogen levels and platelet count are only observed in major cases (shock). Twent-unine patients were subjected to early heparin therapy according to following criteria: shock, preshock, and or presence of multiple coagulation defects. No hemorrhagic complication was observed in treated patients. Only three deaths were recorded; two of them concerned children with severe shock when admitted.

These results, compared with data of the literature and with our former experience in the treatment of meningococcemia without the use of heparin, seem to demonstrate the usefulness of carly anticoagulant therapy in children with meningococcemia.

38. Disseminated intravascular coagulation and respiratory distress syndrome in the nerborn. L. BLFYL. Univ. of Heidelberg, Heildelberg, Germany.

Disscminated intravascular coagulation (D)IC), an "intermediary mechanism of discase," is a common event in cases of intrauterine and perinatal asphyxia and consequent respiratory distress syndrome. Nore than $80 \%$ of autopsy cases with pulmonary hyaline membrancs in the newborn showed fibrinrich multilocular microthrombi, especially in the liver, the lungs, and the suprarenals. As a conscquence of fetal and maternal birth complications, hypoxemia and aciclosis can induce inadequate capillary perfusion and generalized plasmatic hypercoagulability. Circulating plasmatic fibrin monomers and intermediates polymerize intravascularily to disscminated microthrombi, and, after extravatsation, polvmeriec extravascularils to pulmonary hyaline membranes. Haaline membranes as well as DIC must be considered as morphologic equivalents of generalized disorelers of microcirculation with inadequate capillary perfusion, and as morphologic symptoms of shock. Morcorer, DIC in the respiratory distress syndrome indicates that pumonary hypoperfusion must be considered as a symptom of shock, too. Pulmonary hypoperfusion as a typical event in the shock of the newborn and the adult does not only faror the extravasation of fibrin monomers and intermediates into the alreoli, but also induces a marked reduction of the symthesis of the surfactant. Pulmonary hyaline membranes and pulmonary atelectasis are both characteristics of shock-induced respiratory distress.

39. Coagulation studies in the premature infant using micromethods on capillary blood. Preliminary results. A. Hurlet, A. Minkowski, and $F$. Josso. Crr. de Recherches Nenatales du C. H. U. Cochin and C. H. U. N'ecker-linfants Malades, Paris, France.

Methods for clotting factors assays on capillary blood were developed. Accuracy of these assays is good, provided that blood collection is performed very early after the puncture, especially for factor $V$ and $V I I I$ assays.

Factor $I, I I, V I I+X$ and $Y I I I$ assays combined with platelet count were performed in about 100 premature infants on the lst, 2nd. $3 \mathrm{rdl}$, and 10 th days of life. It was sought to define tentatively correlations between the results of these tests and prematurity, possible dysmaturity, and the number of clays after birth.

A decrease of the level of blood-clotting factors, especially factors $I$ and $r$, is often observed in "sick" premature infants, even in the absence of any hemorrhagic tendency.

Several cases of hemorrhagic syndromes related to prematurity have been analyzed. An attempt at prevention of the disseminated intravascular coagulation in the newborn is discussed.

40. Itumoral factors in coagulation disturbances of newborn pathology. I. VIrig and I). Boms. L'niz. of Szeged, Szeged, Hungary.

According to many observations, humoral factors (hormones, vasoactive substances, biologically active metabolites) play an im. portant role in neonatal adaptation clisturbances. On the other hand, serere and multiple blood coagulation disturbances have 
been demonstrated in the same pathologic conditions. The possibility exists that the activity of the blood-clotting factors are influenced by humoral factors, and the abnormalities in the blood coagulation are partly due to accumulated metabolites. Astrup's thromboplastin activation test, standard methods for determining prothrombin complex time and isolated prothrombin activity, and also von Kaulla's thrombin titration method were employed to see whether serum ultrafiltrate of hypoxic guinea pigs influences the coagulation process of normal test plasma. Profound alterations were found: thromboplastin activation was inhibited, the coagulation times in Quick systems and the thrombin times were prolonged. These effects were frequently normalized by prior treatment of the pathologic ultrafiltrate by hydrogen peroxide. Essentially the same was found with the ultrafiltrate of pathologic newhom sera. Our data suggest the existence of humoral effects in hypoxic animals. Such a mechanism in infants is presumably not specific, but an adaptation inrolved in acute pathologic processes. The investigation of humoral effects may represent a new direction in this field requiring further study.

41. Stulies on hypercoagulability of cord and nconatal blood.

(i. Digir.o, M. Orzarlisi, (;. Marzf Trt, A. Tokroni, and D.

Dri. Princinf Cinia of Rome, Rome, tlaly.

The recalcification time ( $\left.R^{\prime} \mathrm{I}\right)$, screening tests on $\mathrm{RT}$, and a modified thromboplastin generation test (TGI) were performed on cord blood and on blood of nomal and hemorrhagic infants in the first days of life. In cord and in normal newborn plasma a significant shortening of $\mathrm{RT}$ was observed in the first $48 \mathrm{hr}$ of life as compared with normal adult plasma. A progressive prolongation of RT was observed from the 2 nd to the 14 th day after birth. The RT of normal adult plasma was markedly shortened by the acldition of 1:10 cord or newhom plasma. Such effect did not appear after tratment of cord blood with ethyl ether or chloroform, or after absorption on BaSO, The TGT performed with cord plasma, absorbed on BaSO, and diluted $1: 10$, showed a more rapid formation and greater activity of hematic thromboplastin as compared with normal adult plasma. 'These results suggest the presence of a procoagulant substance in cord and newbom blood; $62.5 \%$ of 24 hemorragic newbom infants showed the same above-mentioned hemocoagulative patterns. In the remaining hemorrhagic infants, in association with very severe deficits of many coagulatice factors or presence of a circulating anticoagulant, a prolongation of R'T or screcning tests, or both, was observed.

42. Erythro-kinetics of the perinatal period. L.-E. Bratrfby. Eniversity Hosp., Cipposala, Sieden.

The production and life span of the ersthrocytes determine their rate of destruction and change in number per time unit. In the present study the change in amount of circulating erythrocites before and after birth was estimated from neasurements of red cell rolume ( $\mathrm{RC} \mathrm{CY}^{\mathrm{T}}$ ) using a "Cr-technique. Measurements of RCY were performed in newborn infants of a gestational age varying from 222 to 295 days. Repeated RCV estimations vere performed in infants aged $0-138$ days. The destruction of the erythrocytes present at birth was studied as the survival in adult recipients of cord red blood cells Iabeled in vitro with disopropyl${ }^{32}$.fluorophosphate. In the nonkinetic steady state, present during the perinatal period, calculation of the erythrocyte mean life span and distribution of life spans around the mean (life span frequency function) is complicated and possible only if the changes in red blood cell production and destruction are known. In the present study, calculation of red cell production and destruction during the last 2 months of fetal life, the mean life span, and the life span frequency function was made possible using the information of the change in circulating RC:V during the last 2 months of fetal life and the cord red blood cell disappcarance. The crythrocyte production at a gestational age of 220 days varied between 1.5 and $2.8 \mathrm{ml}$, and at 280 dars between 3.5 and $6.8 \mathrm{ml}$ or $3.6-4.2 \%$ and $2.5-3.5 \%$, respectively. The mean destruction was at the same period $0.0 .5 \mathrm{ml}$ and $1-4 \mathrm{ml}$, respectively. The mean life span of the erythrocytes present at birth varied between 45 and 70 days. The frequency function was skew, with the majority of cells dying before the mean life span. The results are considered in relation to data obtained from the literature.

43. Nomal and abnormal synthesis of hemoglobin $A$ and $F$ in the newborn. J. H. P. Joxxis. State Lniw. Hosp., Groningen, The Netherlands.

Reticulocytes and bonc marrow of newly born infants are still able to synthesize hemoglobin $A$ and $F$ during in vitro experiments. The rate of syuthesis of hemoglobin $A$ and $\mathrm{F}$ can therefore be determined in reticulocytes by inculation in vitro with :C-leucine. During these in vitro incubation experiments, the rates of sunthesis of hemoglobin $A$ and $F$ can be detcrmined over a certain period. In normal newborns the hemoglobin $A$ symthesis is greater than that of hemoglobin F. In babies of a gestational age of less than 35 wecks, $80 \%$ of the synthesized hemoglobin is hemoglobin $\mathrm{F}$. In most babies with increased hematopoiesis, the switchover from hemoglobin $A$ to hemoglobin $F$ is rapid. When, however, the erythropoietic stress is excessive, the hemoglobin $\mathrm{F}$ synthesis increases again.

When the synthesis of hemoglobin F decreases. an unequal labeling of the $\alpha \cdot \vec{F}$ and $\gamma$ chains is found, indicating the presence of a pool of $\gamma$ chains. The synthesis of both hemoglobins can be reactivated by adding fresh plasma or already used dialysed plasma to the medium. The presence of a low molecular weight inhibitor of hemoglobin synthesis in the plasma is postulated.

44. Acid lysis of thalassemic erythrocytes. F. Schermivr, A. Matove, and L. Cavatio. Lnive of Bari, Bari, Italy.

Acid lysis of red cells is probably a very indicative index of chemical changes in the membrane and of $\mathrm{Cl}^{-}$and watex content of the cell.

Acicl lysis of crythrocytes from thalassemic major and trait, from iron-deficiency anemia, from newborns, and from normal children, was studied by an automated procedure (Fragiligraph model D)-2). Acid lysis was obtained by submitting the red cell suspension ( $\mathrm{pH} 7.4$ ) to a progressivcly increasing $\mathrm{H}$ ion concentration by clialysis against an isotonic solution of $\mathrm{pH} 2.15$.

Red cells of thalassmia major, of newborns, and of iromdeficiency anemia were more resistant $(P=0.01)$ to the acid lysis and the behavior of thalassemic major cells was intermediate between iron deficiency and newborn cells. In the cells of thalas. semic trait only the time from the start to the initial lysis augmented.

The rate of acid lysis became progressively smaller through the series: normal $=$ thalassemia trait $>$ iron-deficiency anemia $>$ ncwborns $=$ thalassemia major $(P=0.01)$.

The reduction of the acid fragility is probably the result of the 
particular properties of the red cell membrane of newborns, of thalassemic major, and of iron-deficiency anemia.

45. Heinz body formation in red cells of newborn infants. E. Kr.enhaUer and E. KonNe. Unit. of Ulm, Ulm, West Germany.

During the administration of oxidizing agents, red cells of newborn infants are known to be highly susceptible to formation of Ircinz bodies. This phenomenon camnot be explained cither by the type of hemoglobin or by the cnzyme pattcrn typical for fetal exythrocytes.

Studics on Heinz body formation by $\beta$-acetylphenylhydrazine in an in vilro system yiejd the following results. (1) Heinz body formation is not different in red cells before (fetal cells) and after (aclult cells) exchange transfusion. (2) Heins body formation is enhanced in adult red cells after suspending in humau newbotn plasma. (3) The susceptibility to form Heinz bodics is not restricted to a short postnatal period.

Heinz body formation is altered by envirommental factors, most probably by changing the propertics of the red cell membrane.

46. Excretion of erythropoictin and crythropoiesis inhibitors in normal infants and in infants with nconatal polyglobulia. R. Indmarisin and S. Harvorsen. Rikshospitalet, Oslo, Norwa).

A dual regulation of crythropoicsis through stimulators (FSF) and inhibitors (EII) has recently been suggested. F.SF and EIF have been separated in urine from different haematologic disorders $[1 \mid$ It is suggested that the EIF is a chalone [?]. In this study the excretion of ESF and EIF from normal newborn babies and from infants with neonatal polyglobulia has been investigaterl.

Grine from nomal newbom babies, from infants born to diabetic mothers, and from infants with high packed cell volume was collected the first days of life. The urine was divided into volumes corresponding to 6 -hr excretion. The $6 \cdot$ hr volume was passel through a Sephadex G-100 column, and the EIr fraction was collected and tested. ${ }^{\text {an }} \mathrm{Fe}$ incorporation in RBC of exhypoxic, polycythemic and ESF-stimulated mice has been used as assay methor [1]. I'rine from normal ncwborn babies showed no ESF activity. A marked inhibitory effect on erythropoiesis was, however, observed the first days after birth. Crine from infants born to cliabetic mothers, however, showed no inhibitory effect. The possibility of a causal relationship between the increased crythropoiesis and the lack of inhibitors in the latter infants are considered.

1. Lindemamn. R.: Lancel, $i: 781$ (1970).

2. Skjiclaaen, P.. and Halvorsen, S.: Acta Prdiat. Scand., (1971).

47. Leukocyte blood picture in newborn babies cluring and after exchange transfusion. M. Xavthot, K. Tsomides, D. Nicolopolios, and N. Matsaniotis. Univ. of Athens, Athens, Greece.

Serial leukocrte counts were done on 12 full term and 8 premature jaundiced babies during exchange transfusions and daily thereafter up to the 9 th day, in order to study changes in each cell type. The main changes were found to be: $(I)$ a marked reduction in all cell types during the procedure, with a statistically significant difference in absolute values before and after; (2) significantly lower values of the polymorphonuclear neutro- phils and cosinophils in the baby's blood at the end of the transfusion compared with those of the donor's blood, the monocytes and lymphocytes showing no statistically significant change; (3) a remarkable rise in each cell type, reaching 6 times the value found at the end of the procedure, within the weck following the transfusion, a rise which was highly significamt $(P<0.001)$, the highest absolute values of polymorphonuclear neutrophils being well above the upper normal limits (7.000/ $m m^{3}$ ) for the age studied; $(t)$ a similar response in full term and premature babies and following one or multiple transfusions. In conclusion: it was found that the numbers of circulating leukocytes decrease during the exchange transfusion, to rise again soon after the procedure to the preexchange levels and to increase futher within the following week, reaching very high values.

48. Yeonatal diabetes becoming permancnt. S. Ossun, O. Søvik and $\varnothing$. Angris.s. Universily Ilusp., Rikshospitalet, Oslo, Norway.

Two siblings, a boy now 4 years old and a girl now 15 months old, have been studied. The boy showed a steady increase in blood sugar levels from $48 \mathrm{mg} 100 \mathrm{ml} 6 \mathrm{hr}$ after birth to 390 $\mathrm{mg} / 100 \mathrm{ml} 6$ dars later. Insulin treatment was started on the 6 th day, and was continued for nearly 3 months.

He was dysmature with a birthweight of $1840 \mathrm{~g}$. Immunoreactive insulin (IRI) levels were at a low nommal level before treatment. Fasting blood sugar levels have remained normal after treatment was cliscontinued, there is no glycosuria, and blool sugat values following a glucose stimulus are in the normal range. However, both on oral and intravenous testing, there is a very sluggish and diminished IRI response. The sister was also drsmature, birthweight $1440 \mathrm{~g}$. She showed a similar increase in blood stogar levels without ketomuria, and insulin treatment was stanted after 12 dars. Her fasting blood sugar levels have gradually subsided and were in the range of 120)-160 $\mathrm{mg} / 100 \mathrm{ml}$ when insulin treatment was stopped in November 1970. Her glucose tolerance is still grossly abnomal, but she is now well controlled on tolbutamicic. Fasting IRI levels have always been in the low normal range. The results of repeated oral and intrarenous glucose loadings after stop of treatment are in accordance with findings in prediabetic indivieluals.

49. Metabolic effects of feeding in the newborn pig. J. GENTZ, B. Persson, and M. Kr.t.t.M. Karolinska Inst. and S:t Göran's Children's Mosp., Stockholm, Süleden.

Newboms of different species increase their oxygen consumption $\left(\dot{V} \mathrm{O}_{2}\right)$ during the first dars of life. In newborn piglets the influence of feeding and of starvation on $\dot{\mathrm{V}} \mathrm{O}_{2}$, expired carbon dioxide, rectal temperature ( $R T$ ), and on different parameters indirectly reflecting the utilization of substrates such as respiratory quotient (RQ) and levels of blood glucose, free fatty acids (FFA), glycerol, and ketone bodies were studied. Fecding led to a significant rise in "minimal $\dot{V} \mathrm{O}_{2}$ " and $\mathrm{RT}$ during the first days of life; their major increase occurred during the first $24 \mathrm{hr}$. Starvation led to insignificant variations in "minimal $\mathrm{VO}_{2}$ " and $\mathrm{RT}$ in newborn animals, while in older (1-9 days) previously fed piglets $\dot{V}_{2}$ and $\mathrm{RT}$ decreased progressively with starvation, finally reaching values similar to those of the newborns. During starvation in all groups, the changes in FFA glycerol and ketone 
bodies suggested limited lipid mobilization and utilization; the changes in glucose and $R Q$ values indicated increased protein catabolism and ability of gluconeogenesis. The rises in $\dot{\mathrm{V}} \mathrm{O}_{2}$ and $\mathrm{RT}$ following a fixed milk load were greater in newborn than in olcler previously fed animals, and the increases were related to the pretest $\mathrm{VO}_{2}$ also when this had been lowered by starvation in previously fed animals of different ages. A tentative explanation for how feeding effects the rise in "minimal $\mathrm{VO}_{2}$ " during the first days of life is given.

50. Changes in total body water of premature infants in the first 4 days of life. A. I. Murdock. Hammersmith Hosp., London, England.

The prescntly practiced feeding schedule in the premature nursery provide $60,90,120$ and $150 \mathrm{ml} / \mathrm{kg}$ birth weight $/ 24 \mathrm{hr}$ intake of milk ( $62 \mathrm{Kcal} / 100 \mathrm{ml}$ ) from the 1 st to the 4 th day in order. Changes in body composition werc studied using an antipyrine dilution technique for measuring total body water (TBW') on $d a y) l$ and $d a y+$. 'Ten infants of mean birth weight $1905 \mathrm{~g}$ (range $1140-2640$ ) received a mean intake of $105 \mathrm{ml} / \mathrm{kg} / 24$ $\mathrm{hr}$ (range $94-120 \mathrm{ml} / \mathrm{kg} / 2.4 \mathrm{hr}$ ). TBW increased in six infants and decreased in one. The mean change in TBW was $+5 \mathrm{ml} / \mathrm{kg}$ birth weight $(P>0.002)$ orer the 4 -day period. The main change in dry weight was $-52 \mathrm{~g} / \mathrm{kg}$ birth weight $(P>0.001)$ (Dry weight $=$ body weight - TBW). Fluid balance studies and meas. urements of respiratory metabolism with urea nitrogen determinations allowed calculation of change in body water and change in dry weight resulting from the sum of dictary input and tissuc breakdown for heat production in five babies. The results obtained were comparable to those from antipyrine studies. The clata show that the fecling regime provides suflicient water but inadequate calories for solicl tissue growth.

5l. Experimental investigation about peculiarities of pathophysiology of shock in carly age. G. Hollaman, H. D. SChmidt, A. F. Uriban, J. Solc, I). K.iorr, A. Suwatanawiroy, VAREla.Cives, and R. Schadrinke., Kinderklinik, Uniy. München Kinderspital, Munich, Germany.

Puppies in experimental hemorrhagic shock show reactions which can be observed also in shock of newborn and early infancy. In 23 puppies aged 14-21 days and in 20 adult dogs, standardized hemorrhagic shock is performed by the method of Wiggers nodified by Schmier et al. In a constant environmental temperature of $31^{\circ}$, the heart rate, respiratory rate, and rectal temperature decrease in puppies and increase in adult dogs. The stroke volume in puppies is significantly higher than in adult dogs. The concentrations of $\mathrm{H}^{+}, \mathrm{K}^{+}, \mathrm{Ca}^{++}, \mathrm{Mg}^{++}$, adienaline, and noradrenaline increase more quickly and reach a higher level than in adult dogs. Shock tolcrance in puppies is significantly lower than in adult dogs.

These different reactions in shock find possible explanations either by regulatory mechanisms which are effective only in this period of age or by a sudden breakdown of the vital regulatory mechanisms. Aldostcrone scems to be much more important for homcostasis in shock of carly age than in adults. Plasma level of aidosterone in puppies is 3 to 2 times higher than in adult dogs.

52. Fndotoxine-induced circulatory changes in the rabbit. F. WYier and K. Wrisser. University Children's Hosp., Basel, Suitzerland.
The circulatory responses of unanesthetized rabbits were studied 60 and 150 min after administration of endotoxine. Arterial pressure, blood gases, blood $\mathrm{pH}$, and cardiac output (indicatordilution method) were repeatedly measured. Distribution of cardiac output, organ blood flow, and local vascular resistance were calculated after repeated injections of nuclide-labeled microspheres $(50 \mu$ diam.) into the left ventricle.

In spite of a considerable fall in total cardiac output, arterial pressure was well maintained, owing to generalized rasoconstriction. Vascular resistance increased most markelly in the splcen, kidneys, and skin. The effects of endotoxine in the rabbit were compared with those in the monkey, where maintenance of cardiac output and generalized vasodilatation contrasts with the findings in the rabbit. A similar lack of vasoconstriction was observed when the enclotoxine was given to rabbits under halothane anesthesia.

53. Acid-base balance during prolonged nomoxic hypcrcapnia in the newborn. K. P. Riegel, D. Christel, and J. SCHöber. Universitäts-Kinderklinik, Munich, Germany.

In a 2-year period, seven newborns, birth weight 1020-4.400 g, developed hypercapnia ( $\mathrm{PCO}_{2}$ 40-110 Torr) despite artificial ventilation, while other parameters (c.g., Po.a. glucose, and electrolyte metabolism) could be kept in normal ranges. In five infants hypercapnia was present for weeks. Although machanical ventilation did not prevent fluctuations of PCOs, there were stable periods of hypercapnia for clays in any case. Such periods were sclected to define limits of maximal compensation. A first stage of (partial) compensation is reached after $48-7$ ? $\mathrm{hr}$, complete compensation within 5-7 days, depending on the degree of hypercapnia. The ability to defend $H$ ion homeostasis increases with age and duration of hypercapnia. According to the Henderson equation, the bicarbonate concentration necessary for full compensation can be expressed as $\left[\mathrm{HCO}_{3}{ }^{-}\right]=24.47 R$ $\left(R=\mathrm{PCO}_{2} / \mathrm{H}\right.$ ratio $)$. This can be used to calculate $\Delta\left[\mathrm{HCO}_{3}{ }^{-}\right]$for cliagnosis and therapy.

\begin{tabular}{|c|c|c|c|}
\hline & $R=\mathrm{b} \cdot \mathrm{PCn}$ & r) $-a$ & \\
\hline & 1 week & 2 ïcek & $<2$ wiecks of life \\
\hline$N$ & 71 & 35 & 195 \\
\hline Slope $b$ & 0.00642 & 0.01281 & 0.01027 \\
\hline Intercept $a$ & 0.8355 & 0.5117 & 0.7860 \\
\hline$r$ & 0.59 & 0.82 & 0.87 \\
\hline
\end{tabular}

54. Effect on plasma osmolality of rapid intravenous alkali in ncwborn infants with respiratory distress. A. MARINi, F. Cattango, and V. Barbarani. "I. Mangiagalli," Liniv. of Milan, Milan, Italy.

Newborns with respiratory distress $(\mathrm{NRD})$ are often treated with rapid intravenous alkali (RA). This therapy may induce a significant increase of plasma osmolality (PO).

We studied PO after RA with THAM (0.3 1.1$)$ or sodium bicarbonate (NaB) in NRD. Basal values of PO match with those known for the newborn. Both THAM and $\mathrm{NaB}$ induce a marked incrcase of $\mathrm{PO}$ after $3 \mathrm{~min}$; after $20 \mathrm{~min}$ in $\mathrm{NaB}$ cases, PO returns to normal, while a further increase is seen in THAM cases. The slow administration of alkali cloes not influence PO. Changes in PO are not only related to the amount and the kind of alkali, but also to the age (gestational, hours of life) and to the predicted extracellular fluid. 


\begin{tabular}{|c|c|c|c|c|c|c|}
\hline \multirow{2}{*}{ Alkali } & \multirow{2}{*}{-} & \multicolumn{5}{|c|}{ Osmolality, mOsm/liter } \\
\hline & & Initial & & $3 \mathrm{~min}$ & & $20 \mathrm{~min}$ \\
\hline TH.IM & 284 & $(267.292)^{\mathrm{l}}$ & 303 & $(270-318)$ & 307 & $(283-332)$ \\
\hline $\mathrm{NaB}$ & 293 & $(285-302)$ & 325 & $(310342)$ & 295 & $(278-311)$ \\
\hline
\end{tabular}

${ }^{1}$ Values expressed as mean. Numbers in parentheses indicate range.

5j. Biochemical studies during partial perfusion of newborn infants. B. J. ‥ Z. DiNesh and C. H. M. Warkr. Liniv. of Dundee, Dundec Roy al Infrrmary, I) undee, Scotland.

It has been suggested that an extracorporcal-assisted circulation with artificial oxygenators might be used to maintain life in newborn infants with severe cardiopulmonary distress. Such a procedure can in itself lead to further biochemical disturbances such as water and electrolyte tetention, rise in plasma potassium, and development of Iactic acidosis. To control these and to correce the initial respiatory and metabolic imbalances, an artificial hichey has been used in conjunction with an oxygenator in the extracorporeal circuit. The partial perfusion of six new. born infants has indicated that the metabolic clisturbances can be controlled (fficiently by this system. 'The gas-cxchange capacity of the artificial "kidnev-lung" is also more than sufficient, but, owing to the limited blood flow obtainable from one unbilical or femoral catheter. ventilation by this means alone could not be adequately maintained. An alternative to large vesscl cannulation (e.g., carotid) is the coincident use of artificial ventilation during porfusion.

56. Acid-base status of CSF in recurrent neonatal apnca. E. D. Birnard. Women's Hosp., Sydney, Australia.

Acid-base relations between blood and CSF were measured in nine babies (six small prematures, three approaching term) early in the course of recurrent apnea and in the absence of pulmonary or other cliseasc; ages were 1-6 days. A mild decompensated acidosis was found in the blood, but the babies were in a steady state at the time of the CFS examination as judged by trivial difference between the blood then and the specimen 6 hr before. The CSF was alkalotic relative to the blood. In eight controls the normal relation was found.

\begin{tabular}{|c|c|c|c|c|c|c|}
\hline & \multicolumn{2}{|c|}{$11 \mathrm{H}$} & \multicolumn{2}{|c|}{ PCo: mm $\mathrm{Hg}$} & \multicolumn{2}{|c|}{$\mathrm{HCO}_{3} \mathrm{mEq} / \mathrm{liter}$} \\
\hline & Arinea & Control & Apnea & Control & Apnea & Control \\
\hline C.SF & 7.33 & 7.38 & 49 & 37 & 24 & 20 \\
\hline Blood & 7.31 & 7.44 & 45 & 36 & 20 & 24 \\
\hline Difference & $\begin{array}{c}0.02 \\
(P<\end{array}$ & $\begin{array}{l}-0.06 \\
0.05)\end{array}$ & & S) 1 & $\begin{array}{c}4 \\
(P<\end{array}$ & $\begin{array}{r}-4 \\
0.01)\end{array}$ \\
\hline
\end{tabular}

The differences between blood and CSF, by comparison with the controls, was significant for $\mathrm{pH}$ and highly so for bicarbonate. Chloride was $10-15 \mathrm{mEq}$; liter higher in CSF than blood in both groups. All babies lived.

An cxplanation of the findings is not obvious. However, recurrent apnea is a poorly understood syndrome. CSF alkalosis, arising from some temporary anomaly in transport at the bloodbrain barrier, might be a factor in depressing respiratory clrive.
57. Timing of intracranial bleceling in newborn infants. N.

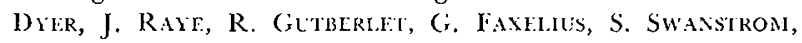
A. Bril.r, and M. Stantanax. l'underbilt Univ. Sch. of Med., Nashville, Tenn., USA.

Intracranial hemorrhage is a frequent finding at autopsy in very immature infants. Because of the possibility of therapy in infants in whom DIC scems to be present, it was thought important to be able to time the intracranial blecel to see whether it had already occurred before therapy coukl have been initiatch. Infants at high risk for intracranial blecding have becen transfused as carly in the course of their illness as possible, with red cells tagged with chromium-50. ${ }^{50} \mathrm{Cr}$ is a stable tracer which can be activated in tiltro to ${ }^{51} \mathrm{C}$ a and counted. If the infunt died and had an intraventricular clot in which $>70 \%$ of the red cells were tagged, it was assumed that bleeding had occurred alter tigging. If the clot contained $<30 \%$ tagged cells as compatred with the sample of blood taken at tagging or just prior to death, it was assumed that bleeding had occured prior to tagging. Twentyeight such tagged infants have died and had intracranial clots analyzed for ${ }^{50} \mathrm{Cr}$. Sixteen infants had HMD, seren extreme immaturty; the remainder died of other disorders. Eighteen wcighed $<1250 \mathrm{~g}, 23$ were $<32$-weck gestation. Median age of tagging was $6.3 \mathrm{hr}$. While median age at cleath was 33.2 hr. ${ }^{\circ 0} \mathrm{Cr}$ concentrations in clot samples indicated that 25 infants had clearly bled after tagging and only ? had aheaty hat their major bleed before lagging; 4 infants presumably had some bleeding before tagging, but continued to bleed afterward. Inrestigations of the possible exchange of ${ }^{\mathrm{o}} \mathrm{Cr}$ tag after clot formation did not indicate significant exchange between tagged circulating red cells and those in the clot. Twelve infants had clear-cut DIC, 11 possible, and 5 had no evidence of DIC. All but one without DIC had grossly abnormal second stage clotting ralues. It is concluded that most of these infants' intracranial hemorrhages occured after birth and after their cliscase was clearly established.

58. Evoked EEG responses in newborns with asphyxia and IRIDS. A. Hrbek, P. Karibirg, I. Kjlitimir, and ' $T$. Olsson. Uniz. of Göteborg and Chalmers Liniv. of Technol., Göteborg, Sweden.

A group of mature and premature newborn infants with asphyxia or IRDS were cxamined. Photostimulation and electrical pulses applicd to the nervus medianus were used. Visual (VER) and somato sensory (SSER)-croked responses were recorded simultancously on an EEG apparatus and on a tape recorder. Responses were averaged with a PDP 12-digital computer. The first results are presented.

In both pathologic states the eroked responses differed conspicuously in form and amplitude from responses in normal subjects. Above all, the initial fast components were affected. The recovery of the responses was very fast in IRDS and slower in asphyctic newborns and was dependent on the severity of asphyxia. In IRUS, a relationship to the oxygen supply was observed. In both disorders studied, VER were much more affected than SsER. The later ones also recovered carlier. The reported preliminary results are encouraging for the clinical application of the evoked responses in neonates.

59. Prolonged intravenous fat administration in low birth weight infants and the effect of heparin. A. Gustarson, I. KJel.t.Mrr, 
R. OlEGiRd, and L. VictoriN. Liniv. of Göteborg, Göteborg, Sueden.

In a previous report (European Soc. Ped. Research, Stockholm, 1970) newborn low birth weight infants were given a single intravenous load of $0.1 \mathrm{~g} / \mathrm{kg}$ body weight of fat emulsion (Intralipid, Vitrum). From the elimination curves a disappearance rate corresponding to a fat tolerance of some $6 \mathrm{~g} / \mathrm{kg}$ body weight $/ 24 \mathrm{hr}$ was calculated. At higher single fat dose $(0.5 \mathrm{~g} / \mathrm{kg}$ body weight $)$ a difference was observed betweeen light for date infants and preterm infants with birth weights appropriate for gestational age. In the light for dates, an early appearing and longlasting increase of the pre- $\beta$-lipoprotein fraction was observed. Concomitantly, the removal rate of exogenous fat decreased. In the present study repeated injections of Intralipid were given hourly during $8 \mathrm{hr}, 0.15 \mathrm{~g}$ fat $/ \mathrm{kg}$ body weight $/ \mathrm{hr}$, corresponding to half the calculated maximal removal capacity. The preterm infants (birth weight appropriate for gestational age) rapidly cleared their plasma after each injection. In the light for datc infants, the plasma concentration of total lipids rose continuously. Forty minutes after the last injection the concentration of plasma total lipids had risen twice as much in the light for date group as in the appropriate for date group. The injection of heparin accelcrated the fat removal in the light for clates. This would indicate an inefficient activity of the lipoprotein lipase in the untreated light for date infant.

60. Exercise studies in children with aortic stenosis. M. R. H. IAYLOR. Inst. of Iis. of the Chest, London Univ., London, lingland.

Studies were performed in children with artic stenesis to determine their exercise tolcrance and cardiopulmonary response to exercise. These tests were performed using a bicycle ergometer. The indirect $(\mathrm{CO})$ Fick method was used to determine cardiac output. It was found that some children could reach a normal maximum work load despite serere aortic stenosis. It was also found that in severe aortic stenosis carcliac output was lower than normal at high levels of rork. It is concluded that exercise testing provides a method of following the progress of children with aortic stenosis and gires uscful information for clinical management.

61. Adriamycin in the treatment of neoplastic diseases of childhood. Effect on lymphoblastic transformation and chromosomcs. I. Massimo, F. Dioni-Bircareliti, P. G. Mori, and F. Cotrtafnva. Unit. of Genoa, Genoa, Italy.

Actriamycin is a new antitumor antibiotic, isolated by Di Marco et al. in 1967 from Streptomyces peucetius caesius. It is similar to claumorubicin: it interferes with nucleic acid metabolism and inhibits their synthesis. The American Association report a group of 16 children suffering from solid tumors, in an adranced stage, treated with adriamycin (6 neuroblastoma, 3 reticulosarcoma, 2 rhabdomrosarcoma, 2 Ewing sarcoma, 2 malignant teratoma, and 1 adenocarcinoma). The highest effectiveness was seen in neuroblastoma, in rhabdomyosarcoma, and in malignant teratoma, where improvement of general condition, decrease in tumor size, and disappearance of pain occurred. Toxic effects consisted of mouth ulcers ( $(1 / 16)$, alopecia (6!16), leukopenia $(7 ! 16)$, and romiting $(2 ! 16)$ and they appeared to be correlated with the single and total dose of the drug. The treatment schedule suggested is a daily dose of $0.5 \mathrm{mg} / \mathrm{kg}$ in $3 \cdot$ day courses for two or three times. Research performed only in the seven children never treated before for the neoplasia showed that lymphoblastic transformation with phytohemagglutinin is not modified, while a moderate increase of chromosome fragmentation ancl a high number of aneuploid cells occur after the treatment with adriamycin.

62. Congenital osteosclerosis in athyreosis. H. ANDrRsfix. Childrens Hosp., Fuglebakken, Copenhagen, Denmark.

A few cases of osteosclerosis in severely hypothyroid children have been reported. Various etiologic factors: renal failure, hypervitaminosis $\mathrm{D}$, disturbances in parathyroid and calcitonin secretion, and so forth, have been considered. The condition seems not to have been observed at birth. Therefore, and to point out also that prenatal changes, presumably in the cartilage, may play a role in this disorder, an athyreotic child with normal serum calcium, phosphorus, and alkaline phosphatase and in whom dense bones were demonstrated immediately after birth is considered.

63. Trro possibly unrecognized clinical syndromcs. R. A. Prifferer. Inst. of Human Genetics, Münster, W'e'st Germany.

I wish to demonstrate two separate syndromes: (l) A variant of pseudopseudohypoparathyroidism in two unclated children. Both children exhibit short stature, mild mental retardation, and visual impaiment due to an infantile glaucoma. There is brachymetacarpy III-V, with cone-shaped epiphyses. The boy in 1956 exhibited also an idiopathic scoliosis, the girl in 1961 suffered from valvular aortic stenosis. (2) Multiple anomalies in tro unrelated bors. Both children exhibit macroccphals; a flat short (puglike) nose with anteverted nostrils, slight protrusio bulborum, small abnormally shaped ears, hrpertrophy of the gingira, bifurcation of the terminal phalange of the thumb, irregularly shaped phalanges, hypoplasia of the scrotum, and a normal-sized penis partially hidden in the suprapubic fat. The elder patient (1962) was mentally' normal. He also showed nonprogressive osteopetrosis. Anomalies of the lumbar vertebrae have recently appeared.

64. Studies on mulibrey-nanism. J. Prerharicter and S. LFistr. Children's Ilosp., Uniu. of Helsinki, Helsinki, Finlund.

In 1970 we reported on a previously unkinown syndrome of proportionate prenatal-onset dwarfism with these characteristics: triangular face with bulging forchead, low nasal bridge, milclly hydrocephalic appcarance, long-shaped sella turcica, thin hypo. tonic extremities, funny high-pitched voice, hepatomegaly, abnormal dispersion of retinal pigment with vellow dots, and slightly or moderately dilated brain ventricles (Perheentupa et al. Acta Pacdiat. Scand. suppl., 206: 74). The name was coined from the words muscle, liver, brain and eye. Mulibrey is distinct from Russel-Silver drvarfism.

We have now studied 11 affected children. The geographical distribution of the ancestors suggests genetic etiology, but familial occurrence has not been obscrved. All except one of the patients were below or at the 10th height and weight percentile for gestational age at birth. The present height was 2.5-6.4 (mean 4.5) sn and the weight 3.4-5.9 (mcan 4.2) sp below the mean for agc. Liver edge was $2-8 \mathrm{~cm}$ below the costal arch at midclavicular line. Several of the patients had liver biopsy with normal histology. Of the six boys, five had varying deguee of fibrous 
bone dysplasia of tibia. Several of the children had large naevi flammei.

The only metabolic abnormality thus far revealed has becn fasting hypoglycemia with acctonuria. This is associated with small glycemic response to glucagon test, undiminished urea excretion, and normal gluconcogenesis from alanine. As we have demonstrated similar patterns of fasting hypoglycemia in other types of primordial dwarfs, we are suggesting that this derangement is an unspecific permanent scqucla of intrauterine stunting.

65. Renal-retinal dysplasia, encephalopathy and glycolipid storage. P. Durand, O. Buggiani, G. Paldamini, B. Brera, and C. Borronf. G. Gaslini Inst., Genou-Quarto; Inst. of Neurol. and Ih'nlal Dis., liniv. of Genoa, Cienoa: Inst. of Comp. Anal., Enive of Rome, Rome; and Inst. of Biol. Chem.. Lniw of Milan, Milan, Italy.

An 8-ycar-old girl with renal dysplasia, similar to juvcnile nephonophtisis, tapeto-retinal degeneration, gradually incicasing mental deterioration, wathing incomelination, obesity, and ictiosis is reported.

Histochemical analyses of the liver, spleen, intestine, lungs, myocardium, kidncys, and brain showed a not identified glycolipid storage. 'The lipid-bound NANA content of the brain was normal, but ganglioside pattern was different from the normal valuc: (;1)2 was considerably greater, and (;)lb and Cill were significantly increased with diminution of (iD)la and G.MI. The activity of some lysosomal acid hydrolases wats increased. The double cousin of the propositus hatl a lapeto-retinal degencration and mental retardation.

A possible defect in the synthesis, also, of tubular cell lipoprotein membrane in hereditary renal-retinal clysplasia is emphasiced.

66. Small intestine disachatrielic inundation. J. C. Mantex. Hopital Sainle- Kugenie, Lyon, France.

We observed cight infants with the nonincidental association: hiatal hernia, dwarfism, mental defect, complex melituria, and osteoporosis possibly complicated with nepholithiasis (J. C. Mamelle, Pédiatrie, 26: 129, 1971). This association is the result of the small intestine disaccharidic inundation by pyloric in. contincence or hypervagotony. Then follow's an early exaggerated postprandial hyperglycemia which induces hyperinsulinism with poststimulating hypoglvcemia. The melituria of exogenous origin (mono- or disaccharicles, or both) is a simple magnification of a physiologic state. The deficiency of calories and proteins secondary to hyperinsulinism is possibly responsible for dwarfism, diffuse osteoporosis, and mental defect. The treatment, at the same time curative and preventive if established early enough, avoids sequels; it consists in slowing down the gastric emptying rate with a thickener. With extent, this syndrome is to be searched after in every infant with or without an esophago-gastric malformation and suffering frem growth failute with delayed bone age, especially if he has cndured a pyloroplasty or pylorotomy, or both (three esophageal atresiae and one hypertrophic pyloric stenosis). Thus every pyloroplasty must be pondered upon. At last the small intestine disacchatidic inundation syndrome is an ctiology of functional hypoglyccmia with hyperinsulinism.

67. The influence of stress on growth hormone concentrations in full term newborn infants. P. SrusBs: and H. Wol. Cniv. of Gö̈ttingen, Cöltingen, Germany.
This study ras performed to evaluate the influence of stress on growth homone $(\mathrm{GH})$, glycerol, and glucose levels in the blood of full term newborn infants at 1,4 , and $\bar{T}$ days of age. Two teams of infants were investigated consisting of three groups with 10 infants each. The first team had intravenous glucose loadings and consequently a series of heel-pricks. The second team had hecl-pricks only without glucose infusion. The results of the second team were thought to be the consequence of skin-pricking representing a stressful procedure, of which vigorous crying was one sign. Skin pricks alone were followed by continuously increasing blood glucose concentrations, whereas the $G H$ response varied within the $1-, 4-$, and 7 -day-old infants, increasing first and then decreasing. After glucose injection, the GH concentration showed a different slope, decreasing initially, and secmed to be contrary to the stress team. 'The variations of growth hormone concentrations during an intravenous glucose loading procedure were corrected for the influencing stress effect and were found to be more pronounced when stress was taken into account. The influence of a stressful procedure was more crident in 2. than in 4-day-old infants and almost wats to be neglected at 7 days of age. The elifferent Gll responses within such a short period of $1-7$ dars may be evidence of adlaptive changes in the early postuatal period of life.

68. Plasma growth hormonc in neonates. (;. B. Forus:s, A. Pojerova, R. Lawrence, and D. SCHilch. L'ni' of hochester, Roce'ster, N'. Y., L'SA.

Plasma growth hormone (GH) levels are high in neonates, but there is great variability which is largely unexplained. In 39 fasting full term infants aged $6-8 \mathrm{hr}$, we found a range of $3-82 \mathrm{ng} / \mathrm{ml}$ (average 18) and at 23-31 hr, 9-86 ng (average 31). A number of possible factors were studied in an attempt to explain the variability, and certain trends were found. Bors tended to have lower lerels than did girls, circumcision done shortly after birth raised the Gill level $(P<0.05)$, and an Apgar score of less than 8 or subnormal body temperature, or both. tended to lower it. Fecding of cow's milk raised the level within 30 min, whereas feeding of plain water lowered it $(P<0.05)$. Type of delivery and maternal premerlication had no effect, nor did the fasting level of blood glucose. A subsample of 11 infants was carefully obscred for $0.5 \mathrm{hr}$ before simpling: status before sampling had no effect, but vigorous crying during the sampling procedure resulted in higher levels.

69. Plasma glucose, insulin, cortisol, and growth hormone responses to glucagon stimulation in newborns. P. C. Sizonenko, G. Tafind, L. Paliner, G. I.tcolrt, and I. J. Konlmr.rg. Clin. L'niversitaire de Pédiatrie, (jeneva, Sititzerland.

In order to incestigate hormonal control of plasma glucose in nconatcs, intravenous glucagon stimulation tests were performed at dosage of $300,30,3 \mu \mathrm{g} / \mathrm{kg}$ in nomal newbolns aged $1-3$ (lays, after a 3-hr fast. Response of plasma glucose $(G)$. insulin (IRI), cortisol $(F)$ and growth hormone (GH) were compared with that of control children aged 5-10 years, tested at 30 and $3 \mu \mathrm{g} / \mathrm{kg}$. Fasting mean $G$ levcls, lower in nconates, were followed by a similar xise in all groups $(29-39 \%)$. IRI levels increased to 108 $153 \mu \mathrm{U} / \mathrm{ml}$ at $3 \mathrm{~min}$ after injection of glucagon. as compared with a mean fasting value of $10 \mu \mathrm{L} / \mathrm{ml}$. No statistical differences between the five groups were observed. A prolonged response 
occurred with higher dosage. Fasting $f$ levels were higher in newborns $(20-36 \mu \mathrm{g} / 100 \mathrm{ml})$, and a similar rise for $F$ was obsexved in all groups $(10-47 \%)$. No significant rise of scrum (iH was observed in control children $(1-5.5 \mathrm{ng} / \mathrm{ml})$. In newborns, GH rose considerably after glucagon (from 19.5-64 to 71.6-1.52 $n \mathrm{~g} / \mathrm{ml})$. Presently, there is no evidence of dose-response eflect of glucagon in any of the groups, with regard to the four parameters investigated. No striking differences were noted between neonates born by vaginal delivery and those born by cesarean section. 'The remarkable response of $\mathrm{GH}$ to glucagon in newbons disappears in the first weeks of life. 'The capacity of the pituitary to secrete $\mathrm{GH}$ should be further craluated in neonatal hypoglycemia.

70. Relation of lipid to carbohydrate metabolism in infants of

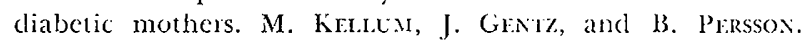
Karolinska Inst. and Sit Gïrans Children's Hosp., Slockholm. Siveden.

Hypoglucosemiat and low free fatty acids (FFA) have been described in infants of diabetic mothers, but because these data are limited, a study was done in 38 infants of insulin-dependent diabetic mothers (ID $M$ s) and 15 infants of gestational diabetic mothers (IGDMs) with cold exposure minimized and where maternal pregnancy care was intensive, similar, and well clefined. Results are compared with those of 22 nomal infants (NL's) (Pcrsson and Tunell. Acta Pcdiat. Scand., in press). Plasma glucose (GLK), FFA, glycerol (GLYC) and $\beta$-hydroxybutyrate (BHB) were determined five times during the finst 2 hre of life. Seventy, thinty, and twenty percent of IDM's, IGDM's and NL's, respectively, had asymptomatic hypoglucosemia. Hypoglucosemic infants were not distinguishable by $\mathrm{FFA}$ values and GIK was not correlated to FFA or GLYC except (for FFA) in IGDM's at $2 \mathrm{hr}$. After $30 \mathrm{~min}$, BHB was similar and low in all groups. The majority of IDM's but only few IGDM's had low FFA relative to GLYC when compared with normals, suggesting decreased lipid mobilization despitc comparable lipolysis. Insulin-dependent diabetic mothers with and without decreased lipid mobilization were compared: in the former group, $k_{G}$ was higher, GI.K was suggestively lower, and maternal prepregnancy insulin doses were higher. Since other measures of maternal diabetic control were comparable, the results suggest that the determinants of abnormal lipicl and carbohydrate metabolism in IDM's may be more complex than "maternal hyperglycemia-fetal hyperinsulinism."

71. Factors influencing the accumulation of bilirubin in amniotic fluid in $\mathrm{Rh}$ hemolytic discase. K. Por.ÁčEK and A. Zwinger. Inst. for the Care of Mother and Child, Prague-Podoli, Czechoslovakia.

The significant negative correlation $(r=-0.63)$ between hemoglobin and bilirubin concentration in the cord blood was found in newborn infants with $\mathrm{Rh}$ hemolytic disease when hydropic fetuses were excluded. The significant positive correlation $(r=0.62)$ between cord blood bilirubin and mild or moderate increase of optical density at $450 \mu \mathrm{m}$ was also found, but there was no such correlation $(r=0.31)$ when the peak of optical density exceeded the value of about 0.1 . It is suggested that in mild cases of fetal hemolytic discase the accumulation of biliary pigment in amniotic fluid is due to the increase of bilirubin content in the fetal extracellular fluid which again is correlated with the fall of hemoglobin. In severe cases of fetal disease, the high binding capacity of amniotic fluid is the main cause of accumulation of bilirubin in the amniotic fluid.
72. Renal response to an oral sodium load and in full term infants. K. Thomevitis, A. Aleria, O. Brobergir, and R. ZFturerströ̀. Karolinska Inst. and S:t Cöran's Cihildren's Ilosp., stockholm, Süveden.

In the newborn infant, renal function is known to be restricted with regard to filtration rate and concentrating and acidifying capacity. Our knowledge about the ability to control sodium homeostasis is rather limited. Since filtration rate is about 20$30 \%$ of that of the 2-year-old child (values related to body surface as well as to weight), it can be cxpected that the ability to excrete sodium is also restricted. Knowledge of the control of sodium homcostasis in the newborn infant is of importance for the calculation of optimal amounts of saline in formula and intravenous infusions. In this communication a study of the control of sodium homeostasis in full term infants is reportcd. The urinary climination of an oral saline load was determincel after saline had been given as $1-2 \%$ solution of a diluted orclinary formula in a total amount of 55 or $110 \mathrm{mEg} / \mathrm{m}^{2}$ body surface. 'The study was carricd out during a constant and fairly high fluid intake. Erine was collected at approximately hourly intervals. The average sodium excretion per hour was calculated. The results were compared with those found in children 2-15 years old, some of them having reduced filtration rate. 'The following results were obtained. (1) The elimination rate of sodium is extremely low even when related to the filtration ratc. (2) 'There is no significant increase in the sodium elimination rate between day 1 and day 10. (3) In contrast to sodium, the excretion of water increases signilicantly from day $l$ to day $10 .(t)$ There is no increase in the climination rate when the amount of saline is doubled. (5) There is an inverse significant correlation between hematocrit and the ability to eliminate sodium. Several possibilities explaining the low sodium elimination rate may be suggested. The results provide information about the maximal sodium tolerance of the infant kidney.

73. Human postnatal gland development: Ductular transport of $\mathrm{Na}^{+}, \mathrm{K}^{+}, \mathrm{H}^{+}$and $\mathrm{HCO}_{3}^{-}$in the single sweat gland of the newborn. D. KaIser, F. Drack, and E. Rossi. Uniz. of Berne, Berne. Stuitzerland.

Derelopment of electrolyte transport in human eccrinc glands can best be studied in the single sweat gland. Using nanoliter analytical techniques, tubular handling of electrolytes was investigated from $0-96 \mathrm{hr}$ of life. Sodium concentration $\left[\mathrm{Na}^{\dagger}\right]$ varicd with sweat rate $(V$, nanoliters per minutc) accorling $10:[\mathrm{Na}]=$ $2.5 \mathrm{~V}+55.0$ on 1st day and approached final values not before 4th clay: $\left[\mathrm{N}_{\mathrm{i}}\right]=2.5 \mathrm{~V}+22.0$. From these data a synchronous $+35 \%$ increase in tubular soclium reabsorption $\left(\mathbf{R}_{\mathbf{x}_{\mathbf{a}}}\right)$ from: $\mathrm{R}_{\mathrm{x} \mathrm{a}}=92 \mathrm{~V}+144\left(10^{-0} \mathrm{~m} \mathrm{Eq} / \mathrm{min}\right.$, lst day) to: $\mathrm{R}_{\mathrm{xa}}=125 \mathrm{~V}+144$ (4th day) could be calculated. Changes for potassium were parallel so that the $\mathrm{Na} / \mathrm{K}$ ratio remained unchanged at 3.0 , which suggests no involvement of adrenal hormones in postnatal sweat electrolyte changes.

Bicarbonate in final sweat approached asymptotically plasma concentrations (24 mFq/liter) thus providing no evidence for active secretion. Nevertheless, occurrence of sweat $\mathrm{pH}$ values (8.0-8.5) strongly alkaline to plasma were observed with increasing age. Simultancous determination of $\mathrm{CO}_{2}$ pressure revealed lower $\mathrm{H}_{2} \mathrm{CO}_{3}$ in sweat than in plasma, which means that with growing age an alkaline "disequilibrium $\mathrm{pH}$ " is established in sweat. 'These results can best be explained by assuming active reabsorption of $\mathrm{H}$ ions by the sweat gland duct. 
74. Neonatal intahepatic cholestasis and $\alpha_{1}$-antitrypsin deficiency. Ø. AhGrias, M. Fagrerhor, and E. Munthe. Rikshospitalet, L'niz. of Oslo, Oslo, Noru'ay.

live patients with $\alpha_{1}$-antiuypsin deliciency and neonatal intrahepatic cholestasis are reported. A short summary of the clinical, light microscopic, and clectron-microscopic lindings is given. Immumohistologic studies on liver biopsics in onc of these paticnts and in one paticnt with $\alpha_{2}$-antitxypsin deficiency and emphysema but no liver disease are reported. liluorescent-labeled antibody against $\alpha_{1}$-antitrypsin was applied to the liver biopsics and showed strong fluorescence in the liver cell cytoplasm, both in the child with cholestasis and in the patient with emphysema. No fluorescence was found in the liver cells of normal children. This seems to indicate that the homozygote $\alpha_{1}$-antitrypsin deficient state (Pi type ZZ), is a condition in which the release of $\alpha_{1}$. antitrypsin from the liver is impaired. Why some of these persons with the $Z Z$ type get liver cirrhosis, some get emphysena, and some are clinically well to old age is so far unsolved.

75. liactionation of xat bone marrow cells. A study model for "stem cells." R. J. HAAs, I. M. FilledNer, and H. D. Fl.m. (iti. for Basic Clin. Res., Univ. of Ulm, Ulm, ciermany.

Rats were labeled with ${ }^{3}$ I-thymidine ("I I-T,IR) in utero and for ( $)$ weeks after birth in order to obtain $100 \%$ labeling of all bone marrow cells. Six wecks after the last ${ }^{5} \mathrm{H}-\mathrm{T} d \mathrm{R}$ injection only cytokinctically resting cells were still labeled. At this time the regenerative capacity of fractions obtained after centrifugation by means of a cliscontinuous albumin gradient was tested in 1200 $r$-inadiated recipients and the results were compared with the effect observed after transplantation of identical amounts of unfractionated bonc marrow cells. One of the fractions obtained produced a 10 -fold increase in regeneratory capacity. This fraction was found to contain a concentration of undifferentiated blast cells and the highest amount of cytokinetically resting bone marow lymphocytes as compared with all other fractions. In contrast, when the response to a phytohemagglutinin stimulation test was evaluted, this fraction showed a decreased incorporation of ${ }^{14} \mathrm{C}-\mathrm{TdR}$ as compared with other fractions. 'The findings indicate a possible correlation between cytokinetically resting cells or blast cells, or both, and the regeneratory process after lethal $\mathrm{x}$-imadiation.

76. Function of exocrine pancreas in newborns. G. ZorpI, G. ANoreotTl, I. PAjno-FrrrarA, and D. Gaburro. Univ. of V'erona, V'erona, Llaly.

The function of exocrinc pancreas has becn studicel in $3 \cdot t$ newborns by means of a double balloon threc-lumen polyvinylcatheter tube and intravenous stimulation with pancreozymin and secretin. The patients of the first group) (16 premature babies with a gestational age between 32 and 34 wecks and a weight at birth between 2.0 and $2.4 \mathrm{~kg}$, and 8 full term newborns with a weight between 3.6 and $4.0 \mathrm{~kg}$ ) were fed the same formula and the test was performed before the first fecling, $24 \mathrm{hr}$ thereafter, at 1 weck, and 1 month of life in order to state the influcnce of prematurity on pancreatic response to hormonal stimulations. Enzyme activities at birth werc lower in premature than in full term newborns and became higher at 1 week of life. The patients of the sccond group (10 premature babics with a gestational age and a weight at birth similar to premature babies of the first group) were fed skimmed milk containing $2 \%$ soluble starch or
2\% glucose. Induction of pancreatic $\alpha$-amylase by stauch was observel.

77. Transport of amino acid residues of peptides across the intestinal brush border. $A$. Ruвiso and M. Fifin. Harvard Med. Sch., Children's Hosp. Med. Cor., and Beth Israel Hosp., Boston, Malasachusetts, USA.

To unclerstand better the pathophysiology of protein malabsorption, more knowledge of the digestive-absorptive process for peptides is required. All glycine (Gly) which is accumulated in rabbit ilem incubated with glycyl-L-proline (Gly-Pro) is in the free form, but this Gly enters the cell by a saturable system unshared by Gly free in the Iumcu (Rubino e't al.: Pediat. Res., $f: 477,1970)$. The transport of the Pro residue of (ily-Pro is now studied by measuring uptake of $\left({ }^{3} \mathrm{H}-\mathrm{P}\right.$ ro) (ily-Pro by rabbit ilcum. This process follows saturation kinetics and has a low aflinity for frec Pro: percentage of control influx ( \pm 1 sr: of $0.5 \mathrm{~m} \times\left({ }^{3} \mathrm{H}-\mathrm{P}^{\prime} \mathrm{ro}\right)$ Gly-Pro in presence of $20 \mathrm{~m} \mathrm{M}$ Pro is $92.4 \pm 7.1$; influx of $1 \mathrm{~mm}{ }^{3} \mathrm{H}$. Pro is unaffected by $20 \mathrm{~mm}$ Glr.Pro. To study where hyclrolysis occurs, tissue uptakes of ${ }^{3} \mathrm{H}$ and ${ }^{2} \mathrm{C}$ are simul. tancously measured after brief exposure to $\left({ }^{3} \mathrm{H} \cdot \mathrm{PrO}\right)$ - and $\left({ }^{1 .} \mathrm{C}\right.$ (ily)(ily-P'ro. ${ }^{14} \mathrm{C}$ uptake ${ }^{3} \mathrm{H}$ uptake ratios at 0.5 , 2, and $t \mathrm{~mm}$ Gly-Pro concentrations are $1.4 \pm 0.04,1.4 \pm 0.05$, and $1.3 \pm 0.04$, respectively, indicating that a back flux of Pro, without a corresponding Gly eflux, is rapidly initiated. It is concluded that hydrolysis occurs, at least in part, in the brush border and the icleased Gly and Pro are then translocated by way of sistems unshated by Gily and Pro free in the lumen.

78. Vilumin E absorption in children. J. T. H.rrrifs, D. P. R. Mcr.rire, and J. K. Liovo. Inst. of Child Illth., London, linglend.

The intestinal absorption of vitamin $\mathrm{E}$ ( $\alpha$-tocopheryl acetate) has been studied in 86 children: cystic fibrosis of the pancreas $(-17)$, obstructive jaundice (17), celiac discase (10), abctalipoproteinemia (7), and intestinal lymphangiectasia (5). Each group represcnts an experimental model in which one or more of the known absorptive steps for vitamin $\mathrm{E}$ absorption are absent or defective. The vitamin $\mathrm{E}$ status of the patients ras assessed by cstimating serum concentration of vitamin $\mathrm{F}$ and peroxide hemolysis. Before vitamin $\mathrm{E}$ administration the mean serum levels of vitamin $\mathrm{E}$ and peroxide hemolysis in the 86 children with malabsorption were $0.23 \mathrm{mg} / 100 \mathrm{ml}=0.16$ (1 sp) and $35.8 \%+28.5$ (1 su), respectively, compared with 21 children without malalssorption who had mean levels of $0.80 \mathrm{mg} / 100$ $\mathrm{ml} \div 0.18$ and $1.89 \% \pm 2.15$. Deficiency was greatest in obstructive jaundice and abetalipoproteinemia. Absorption was further investigated by assessing the response to short and long term aclministration of differing closes of fat-soluble and water-miscible preparations of vitamin $\mathrm{E}$, and the results suggest that the following factors arc important for absorption. (1). Bile is of major importance. (2). Within the intestine, both bile and pancreatic lipase are necessary for solubilization of the vitamin. (3). The jejunum is an important site for vitamin $\mathrm{E}$ absorption. (4). The majority of vitamin $\mathrm{E}$ is probably transported from enterocytes via lymphatic chammes in association with chylomicrons. (5). Chylomicron formation is not obligatory for absorption, and in conditions where chylomicrons camnot be formed (abctalipoproteincmia) absorption can occur by way of the portal rein. 
79. Chemical changes in a patient with $\mathrm{Gm}_{1}$ gangliosidosis $t y p e$ I. C. Borrone and B. Berra. G. Gaslini Inst., Genoa-Quarto, and Inst. of Biol. Chem., Unit. of Milan, Milan, Italy.

A case of $\mathrm{Gm}_{1}$ gangliosidosis type $I$ has been studied from clinical, radiologic, histologic, histochemical, and chenical points of view.

Hurler-like morphologic and racliologic features, early appearence and rapid course, and presence of a cherry-red spot at funclus oculi suggestcd a generalized gangliosidosis. $\beta$-Galactosidasic activity seemed to be absent in liver. A careful study of gangliosicles isolated from different cerebral districts and different organs (liver, spleen, lung, kidney, myocardium, thyroid, and mediastinic lymph node) showed an increase of gangliosides content, and, on thin layer chromatography, an increase in $\mathrm{Gm}_{1}$ ganglioside percentage, especially evident in cucephalon $189.9 \%$ in the bridge).

An acid mucopolysaccharide isolated from liver, whose features are not yet defined, is now under study.

80. Pathogenetic studics in leukodystrophy. $\times$. Hrkscilkowry and $A$. Kohlss Hürrer. Univ. of Berne, Berne, Switzerland.

"Jimpy" is a genetically determined leukodystrophy in the mouse, in which the nervous system is practically devoid of myelin. This disorder can serve as a model for human leukodystrophies of a similar type.

Our investigations show that in the "jimpy" mouse myclin is lacking in the central but not in the peripheral nervous system. Neither ultrastructural nor biochemical evidence (cholesterol ester) for increased myelin break (lown could be observed. However, enzymatic activitics for the synthesis of myelin compounds such as sulfaticle was significantly recluced in vitro and in vivo in the central nerrous system. Inhibition of enzyme activity could be excluded by in vitro mixing experiments. Normal enzyme activities were found in the peripheral nervous system and in the kidney. The postnatal development of myelin was studied by separating several myelin-like fractions by density gradient ultracentrifugation. In the normal mouse, around the llth day, myelin-like fractions disappear and true myelin with the characteristic physical and chemical qualitics appears. In the "jimpy" mouse no such devclopment could be observed. With an aclaptation of method for neuron and glia separation by Norton (Science, 167: 1144, 1970), we found that ${ }^{5}$ S-sulfatide synthesis was impaired in both cell fractions. The fact that the activity of several enzymes is decreased in the "jimpy" brain but $K_{n}$ and electrophoretic pattern is normal, makes it possible that the primary defect is a mutation in the operator gene.
81. Mucolipidosis $I$ and $I I$ : Evidence for different biochemical lesions. U. WiesmanN and N. HerschkowtT. Univ. of Berne, Berne, Switzerland.

Mucolipidosis I (MLp) is a genetic disease with severe progressive mental retardation and skeletal abnormalities, resembling a mucopolysaccharidosis but with normal amounts of urinary mucopolysaccharides (MPS). MLp II is a similar genctic disorder but with milder clinical manifestations. Cultured fibroblasts from type $I$ show cularged cells with granular material (I-ccll phenomenon). Metachromasia is found after lipid extraction and intracellular MPS is increased. We report on our results on fibroblasts of a patient with MLp $I I$. The I-cell phenomenon and metachromasia could be demonstrated. A significant clecrease in the activities of seven lysosomal enzymes but nomal values for milochondrial and cytoplasmic enzymes were found in the cells. In fibroblasts from the parents, intermediate values were found. The degradation of ${ }^{35} \mathrm{SO}_{1}$ MPS and of ${ }^{35} \mathrm{SO}_{4}$-sulfatide was greatly impaired. In the media in which the cells had bcen grown for 3 days, the activities of fire lysosomal enzymes were increased as compared with nedia from normal cells. Increased cellular death and reduced enz'matic inactivation in the media, causing the elevated enzyme activities, could be excluded and leakage of lysosomal enzymes has to be considered as the most possible cause of the multiple enzyme deficiency. Iibroblasts from t) pe I also showed decreased lysosomal activitics, but no leakage of enzymes into the media was observed. Thus two different etiologics for these disorders are to be assumed.

82. Hexeditary galactokinase deficiency. J. G. H. Cook, N. A. Dox, and T. P. MANN. Royal Alexandra Hosp. for Sick Children, Brighton, England.

A baby with galactokinasc deficiency, a recessive inborn error of galactose metabolism, is described. The case is exceptional in that there was no evidence of gypsy blood in the family conconed. The investigation of neonatal hyperbilirubinemia led to the discovery of galactosuria. As noted by others, the paucity of prescnting features makes early diagnosis difficult, and detection by biochemical screening secms desirable. Cataract formation, of carly onsct, scems to be the only severe persisting complication and may be due to the biosynthesis and accumulation of galactitol in the lens. The paucity of manifestations in the few cases so far identified in the newborn period throws some light on the symptom complex of the allied transferase defect (congenital galactosemia). Ophthalmic surgeons need to be aware of this enzyme defect, because with early diagnosis and dietary treatment these lens changes should be reversible. 